\title{
Modernising English Criminal Legislation 1267-1970
}

\author{
Graham McBain $^{1,2}$ \\ ${ }^{1}$ Peterhouse, Cambridge, UK \\ ${ }^{2}$ Harvard Law School, USA \\ Correspondence: Graham McBain, 21 Millmead Terrace, Guildford, Surrey GU2 4AT, UK. E-mail: \\ gsmcbain@aol.com
}

Received: April 2, 2017 Accepted: April 19, 2017 Online Published: April 27, 2017

doi:10.5539/par.v6n1p53 URL: http://dx.doi.org/10.5539/par.v6n1p53

\section{INTRODUCTION}

English criminal - and criminal procedure - legislation is in a parlous state. Presently, there are some 286 Acts covering criminal law and criminal procedure with the former comprising c.155 Acts. Therefore, it is unsurprising that Judge CJ, in his book, The Safest Shield (2015), described the current volume of criminal legislation as 'suffocating'. ${ }^{1}$ If one considers all legislation extant from 1267 - 1925 (see Appendix A) a considerable quantity comprises criminal law and criminal procedure - most of which is (likely) obsolete. ${ }^{2}$

Given this, the purpose of this article is to look at criminal legislation in the period 1267-1970 as well as criminal procedure legislation in the period 1267-1925. Its conclusions are simple:

(a) the Law Commission should review all criminal legislation pre-1890 as well as a few pieces thereafter (see Appendix B). It should also review (likely) obsolete common law crimes (see Appendix C);

(b) at the same time, the Ministry of Justice (or Home Office) should consolidate all criminal legislation post-1890 into 4 Crime Acts. ${ }^{3}$ These should deal with: (a) Sex crimes; (b) Public order crimes; (c) Crimes against the person; (d) Property and financial crimes (see 7). Once consolidated, any common law crimes which are not obsolete (see Appendix C) should be added to these Crime Acts.

In the case of (a) I have previously analysed many of these pieces of legislation in prior articles (as noted in the Appendix B). Thus, this article will only concentrate on those items of criminal legislation not previously analysed.

The conclusion to this article is clear. It is perfectly possible to consolidate all criminal legislation into 4 Acts, providing early, obsolete, legislation is removed.

\section{LEGISLATION - STREET CRIMES}

Among the earliest minor crimes known to English law, there were 'street' crimes. For example, digging up, or diverting, a street. This is mentioned in the Laws of Henry I (c.1113) as stretebreche (street breach). However, it is (likely) much older. Possibly, Anglo-Saxon. ${ }^{4}$

- Other street crimes may be seen in the early laws of London - such as a City Ordinance of 1277 prohibiting people from throwing rubbish (filth) in the streets. ${ }^{5}$ This and others (such as letting pigs wander in the street etc) were punished as nuisances (annoyances) to the community. These were punished under the common law crime of common (public) nuisance where legislation did not otherwise provide;

- However, in early Victorian times, legislation enumerated various street crimes. One of the first was the City of London Police Act 1839 (repealed). It sought to gather together various old City street crimes into a more modern format (as well as clarify what they were). These street crimes was extended to the Metropolitan Police District of

\footnotetext{
${ }^{1}$ I Judge, The Safest Shield (2005), p 97.

${ }^{2}$ I calculate the figure is, at least, c. $85 \%$.

${ }^{3}$ The word 'crime' is a better (and shorter) word than 'offence'.

${ }^{4}$ See GS McBain, Abolishing the Crime of Public Nuisance and Modernising that of Public Indecency (2017) International Law Research, vol 6, no 1, pp 1-108 especially, pp 10 (royal roads) \& 14 (stretebreche). It may be noted that Anglo-Saxon law did not draw a distinction between civil and criminal offences (which also explains why a public nuisance can give rise to both civil and criminal remedies today). See also J Bosworth, A Compendious Anglo-Saxon and English Dictionary (1868)(stret) 'a street'.

${ }^{5}$ Ibid, p 30.
} 
London ('MPD') by the Metropolitan Police Act 1839 (the '1839 Act', still extant). They were then extended to urban areas by the Town Police Clauses Act 1847 (the '1847 Act') as amended by the Public Health Act 1875, s 171 (both still extant). ${ }^{6}$ There were also various Highways Acts, such as the 1835 Highway Act 1835 which sought to deal with obstructions to the streets.

Extant legislation on street crimes in the period 1267-1890 comprises the following:

\section{(a) Highway Act 1835}

This Act, section 72 states:

- $\quad$ s 72 (Footpaths). 'If any person shall wilfully ride upon any footpath or causeway by the side of any road made or set apart for the use or accommodation of foot passengers; ${ }^{7}$ or shall wilfully lead or drive any horse, ass, sheep, mule, swine, or cattle or carriage of any description, or any truck or sledge, upon any such footpath or causeway; or shall tether any horse, ass, mule, swine, or cattle, on any highway, ${ }^{8}$ so as to suffer or permit the tethered animal to be thereon...'; [penalty, level 2]

In essence, then, it is a crime to: (i) intentionally ride on a footpath or footway; (ii) intentionally lead (or drive) a horse etc. or truck etc. on a footpath or footway; (iii) tether a horse etc. on any highway (or permit the same). This section is general legislation. It may be compared with similar sections in the 1839 Act (which applies to the MPD only) and the 1847 Act (which applies to urban districts only), viz:

- $\quad 1839$ Act s 54(7) 'Every person who shall lead or ride any horse or other animal, or draw or drive any cart or carriage, sledge, truck, or barrow, upon any footway or curbstone, or fasten any horse or other animal so that it can stand across or upon any footway.' (italics supplied). This section should have been repealed by the Deregulation Act 2015, sch 23, pt 9; ${ }^{9}$

- $\quad 1847$ Act, $\mathbf{s} 28$ 'Every person who leads or rides any horse or other animal, or draws or drives any cart or carriage, sledge, truck, or barrow upon any footway of any street, or fastens any horse or other animal so that it stands across or upon any footway.' (italics supplied). This section was repealed by the Deregulation Act 2015, sch 23, pt 9. ${ }^{10}$

These local Acts cover (covered) much the same as the Highway Act 1835, s 72 - save that the wording in the 1847 Act is more modern. The Highway Act 1835 also states:

- $\quad$ s. 78 (Drivers of waggons or carts) '... if the driver of any carriage whatsoever on any part of any highway shall by negligence or wilful misbehaviour cause any hurt or damage to any person, horse, cattle, or goods conveyed in any carriage passing or being upon such highway, or shall quit the same and go on the other side of the hedge or fence inclosing the same, or negligently or wilfully be at such distance from such carriage or in such a situation whilst it shall be passing upon such highway that he cannot have the direction and government of the horses or cattle drawing the same, or shall leave any cart or carriage on such highway so as to obstruct the passage thereof; ...; or if the driver of any waggon, cart, or other carriage whatsoever, or of any horses, mules, or other beast of draught or burthen meeting any other waggon, cart, or other carriage, or horses, mules, or other beasts of burthen, shall not keep his waggon, cart or carriage, or horses, mules, or other beasts of burthen, on the left or near side of the road; or if any person shall in any manner wilfully prevent any other person from passing him, or any waggon, cart, or other carriage, or horses, mules, or other beasts of burthen, under his care, upon such highway, or by negligence or misbehaviour prevent, hinder, or interrupt the free passage of any person, waggon, cart, or other carriage or horses, mules, or other beasts of burthen, on any highway, or shall not keep his waggon, cart, or other carriage, or horses, mules, or other beasts of burthen, on the left or near side of the road, for the purpose of allowing such passage; or if any person riding any horse or beast, or driving any sort of carriage, shall ride or drive the same furiously so as to endanger the life or limb of any passenger; ${ }^{11}$ [penalty, level 1] (italics supplied)

This section is very convoluted. However, in essence, it is a crime if the driver of a carriage on a highway:

- $\quad$ Injure a Person, Animal etc - by negligence or wilful misbehaviour [i.e. intentionally] cause any hurt or damage to any person, horse etc or goods conveyed in any passing carriage;

- Drive other than on the Highway - quit the same [i.e. the highway] and go on the other side of the hedge or fence inclosing the same;

\footnotetext{
${ }^{6}$ Ibid, pp 63-4. The Public Health Act 1875, s 171 states: 'The provisions of the [1847 Act], with respect to the following matters, (namely. (1) with respect to obstructions and nuisances in the streets; and (2) with respect to fires; and (3) with respect to places of public resort; and (4) with respect to hackney carriages; . . . shall, for the purpose of regulating such matters in urban [districts], be incorporated with this Act.' Cf. Highways Act 1980, s 329 (footway). See also Oxford English Dictionary (causeway) 'A highway; usually a paved way, such as existed before the advent of macadamization. Now historical or forming the part of ancient ways, esp, the Roman roads, the military roads of the 17th century etc...'. The word 'causeway' is not now used.

${ }^{8}$ Highway Act 1835, s 5 'In the construction of this Act...the word 'highways' shall be understood to mean all road, bridges...carriageways, cartways, horseways, bridleways, footways,causeways, churchways, and pavements.' See also Halsbury, Statutes (4th ed), vol 36 and cases cited therein.

${ }^{9}$ This should have been repealed since the equivalent section in the 1847 Act, s 28 (which covers urban districts) was repealed.

${ }^{10}$ See $\mathrm{n} 28$.

${ }^{11}$ By the Local Government Act 1888, s 85(1) bicycles, tricycles etc are directed to be carriages within the meaning of the Highways Acts. By the Road Traffic Act 1988, s 19(1) the general law relating to carriages is applied to motor vehicles and trailers.
} 
- $\quad$ Not control the Carriage - negligently or wilfully be at such distance from such carriage or in such a situation while it passes that he cannot have the direction and government [i.e. control] of the horse etc drawing it;

- $\quad$ Obstruct the Highwav - leave any carriage on the highway, obstructing it;

- $\quad$ Not Keep to the Left - meeting any other carriage, or horse etc, shall not keep his carriage, or horse etc. on the left or near side of the road;

- $\quad$ Prevent Passage - wilfully prevent any other person from passing him or other carriage, horse etc. under his care, on such highway;

- $\quad$ Hinder Passage - by negligence or misbehaviour prevent, hinder, or interrupt the free passage of any person, carriage, horse etc on any highway;

- $\quad$ Not Keep to the Left - not keep his carriage, horse etc on the left or near side of the road, for the purpose of allowing such passage;

- $\quad$ Ride Furiously - ride a horse etc or carriage furiously, to endanger the life (or limb) of any passenger.

This section 78 may be compared with sections in the 1839 and 1847 Acts which are narrower in scope:

- $\quad$ 1839 Act, s 54(4) 'Every person having the care of any cart or carriage who shall ride on any part thereof, on the shafts, or on any horse or other animal drawing the same, without having and holding the reins, or who shall be at such a distance from such cart or carriage as not to have the complete control over every horse or other animal drawing the same.' Also, s 54 (5) ' Every person who shall ride or drive furiously, or so as to endanger the life or limb of any person, or to the common danger of the passengers in any thoroughfare...'.These sections should have been repealed by the Deregulation Act 2015, sch $17 ;^{12}$

- $\quad \mathbf{1 8 4 7}$ Act, s 28 'Every person having the care of any waggon, cart, or carriage who rides on the shafts thereof, or who without having reins, and holding the same, rides upon such waggon, cart, or carriage, or on any animal drawing the same, or who is at such a distance from such waggon, cart, or carriage as not to have due control over every animal drawing the same, or who does not, in meeting any other carriage, keep his waggon, cart, or carriage to the left or near side, or who in passing any other carriage does not keep his waggon, cart, or carriage on the right or off side of the road (except in cases of actual necessity, or some sufficient reason for deviation) or who, by obstructing the street, wilfully prevents any person or carriage from passing him, or any waggon, cart, or carriage under his care.' Also , 'Every person who rides or drives furiously any horse or carriage, or drives furiously any cattle.' These sections were repealed by theDeregulation Act 2015, sch $17 .{ }^{13}$

The Highway Act 1835 should be repealed and ss $72 \& 78$ be inserted in the Highways Act 1980 to the extent considered by the Department for Transport ('DfT') necessary. It may be noted that the Highways Act 1980 contains its own definitions of 'highway', 'footpath', 'footway', 'carriageway', 'bridleway', 'street' and 'horse'. ${ }^{14}$

\section{In conclusion, the Highway Act 1835 should be repealed and these crimes (to the extent necessary) placed in the Highways Act 1980, with more modern wording.}

\section{(b) Metropolitan Police Act 1839}

This Act only covers the MPD. However, it was used as the basis for the 1847 Act which applies to urban districts. As previously noted, ${ }^{15}$ an error was recently made in respect of this Act in that various minor crimes were repealed in the 1847 Act but not in this one. The result is that certain street acts can still be crimes in the MPD but not in urban districts (and not at all in the City of London). This is undesirable since it creates - in effect - 'crime by post code.' It is asserted that this Act should be wholly repealed for the following reasons:

- $\quad$ Street Processions. Two sections relate to these. ${ }^{16}$ These only apply to the MPD. Equivalent sections are to be found in the 1847 Act, ss $21 \& 23$ (see (c)). These sections in both Acts should be repealed and the DfT should make similar provision (as modernised) in the Highways Act 1980;

- $\quad$ Fairs. Two sections relate to these, ss 38 and 39:

Section 38 provides that fairs in the MPD may not operate between $11 \mathrm{pm}$ and $6 \mathrm{am}$. Thus, anyone managing a stall, booth etc. open between those hours is guilty of a crime. So too, any person who fails to quit the same on being told by a police constable to do so. ${ }^{17}$

\footnotetext{
${ }^{12}$ See $n 9$.

${ }^{13}$ See n 28.

${ }^{14}$ Highways Act 1980. s 329(1).

${ }^{15}$ See $n 9$.

${ }^{16}$ e.g. 1839 Act, ss 52 (regulations for preventing obstruction in the streets during public processions) and 53 (deviation permitted when in accordance with the regulations in $\mathrm{s} 52$ ).

${ }^{17}$ Ibid, s 38 'The business and amusements of all fairs holden within the [MPD] shall cease at the hour of eleven in the evening, and shall not begin earlier than the hour of six in the morning; and if any house, room, booth, standing, tent, caravan, waggon, or other place shall, during
} 
Section 39 deals with where a fair has been unlawfully held (because there was no right to hold it) or where it has continued beyond the stated period. In such cases, persons driving fair carriages (and those therein) as well as - 'every person resorting to [it] with any show or instrument of gambling or amusement' - commits a crime. ${ }^{18}$

Fairs, for the purpose of this Act, were not the same as markets. ${ }^{19}$ They were annual events, many long standing. However, it is unlikely that any fairs now exist in the MPD since most London fairs were abolished in Victorian times (on the grounds of being disorderly) pursuant to the Fairs Act 1871 (still extant). ${ }^{20}$ Also, even if such fairs still exist, the Markets and Fairs Clauses Act 1847 (still extant) enabled byelaws to be made for fairs, including the time and hours of operation. Thus, it is likely that MPD fairs would now be governed by the same. In any case, the crimes in the 1839 Act are replicated - to an extent - in the Metropolitan Fairs Act 1868, s 2 (extant) ${ }^{21}$ which applies in respect of any fair in the MPD 'other than that on which a fair has been holden during each of the seven years immediately preceding'. ${ }^{22}$ In light of all this:

(a) it is asserted that these sections in the 1839 Act - as well as the Metropolitan Fairs Act $1868^{23}$ should be repealed. Such acts should not be crimes today. ${ }^{24}$ In any case, these sections appear to have produced no caselaw since 1847 (or 1868) - a good indication there are unlikely to be any fairs in the MPD still held (fairs held in London parks would be governed by their byelaws);

(b) no similar legislation to sections 38 and 39 of the 1839 Act apply to the City of London or to urban districts. Thus, sections 38 and 39 are anomalous.

Given this - and the fact that there appear to be no markets or fairs in England and Wales operating today by way of Crown or local legislation ${ }^{25}$ it would also seem appropriate for the Law Commission to appoint an expert to review the law on markets and fairs. In particular, to consider the repeal of the Markets and Fairs Clauses Act 1847

the continuance of any such fair, be open within the hours of eleven in the evening and six in the morning for any purpose of business or amusement, in the place where such fair shall be holden, it shall be lawful for any constable to take into custody the person having the care or management thereof, and also every person being therein who shall not quit the same forthwith upon being bidden by such constable so to do; and the person so then having the care of management of any such house, room, booth, standing, tent, caravan, waggon, or other place, shall be liable to a penalty not more than [level 1], and every person convicted of having been therein, and of not having quitted the same forthwith upon being bidden by a constable so to do, shall be liable to a penalty not more than [level 1].' (italics supplied)

${ }^{18} \mathrm{Ibid}, \mathrm{s} 39$. 'If it shall appear to the commissioners of police that any fair ... holden within the [MPD] has been holden without lawful authority, or that any fair lawfully holden within the said district has been... holden for a longer period than is so warranted, it shall be competent to such commissioners to direct one of the superintendents belonging to the metropolitan police force to summon the owner or occupier of the ground upon which such fair is...holden to appear before a magistrate at a time and place to be specified in the summons, not less than eight days after the service of the summons, to show his right and title to hold such fair, or to hold such fair beyond a given period (as the case may be); and if such owner or occupier shall not attend in pursuance of such summons, or shall not show to the magistrate who shall hear the case sufficient cause to believe that such fair has been lawfully holden for the whole period during which the same has been... holden, the magistrate shall declare in writing such fair to be unlawful, either altogether or beyond a stated period (as the case may be); and the commissioners shall give notice of such declaration by causing copies thereof to be affixed on the parish church and on other public places in and near the ground where such fair has been ...holden; and if, after such notices have been affixed for the space of six days, any attempt shall be made to hold such fair if it shall be declared altogether unlawful, or to hold it beyond the prescribed period if it shall be declared unlawful beyond a certain period, the commissioners of police may direct any constable to remove every booth, standing, and tent, and every carriage of whatsoever kind conveyed to or being upon the ground for the purpose of holding or continuing such fair, and [to take into custodyl every person erecting, pitching, or fixing, or assisting to erect, pitch, or fix, any such booth, standing, or tent, and every person driving, accompanying, or conveyed in every such carriage, and every person resorting to such ground with any show or instrument of gambling or amusement [shall be guilty of an offence]; and every person convicted before a magistrate of any of the offences last aforesaid shall be liable to a penalty not more than [ level 1].' (italics supplied). See also s 40 (recognizance).

${ }^{19}$ See GS McBain, Abolishing some more Obsolete Crown Prerogatives: Pt 2 (2011) Liverpool Law Review, vol 32, pp $279-84$.

${ }^{20}$ Ibid, p 282, fn 44. See also Fairs Act 1871. Ibid, p 283.

${ }^{21}$ viz. 'Where any fair is holden or notice is given of any fair proposed to be holden on any ground within the [MPD] other than that on which a fair has been holden during each of the seven years immediately preceding, it shall be competent for the Commissioner of Police to direct one of the superintendents of the Metropolitan Police Force to summon the owner or occupier of the ground upon which such fair is holden to appear before a magistrate forthwith, or at a time to be specified in the summons, to show his right and title to hold such fair; and if such owner or occupier do not attend in pursuance of such summons, or does not show to the magistrate who hears the case sufficient cause to believe that such fair is lawfully holden, the magistrate shall declare in writing such fair to be unlawful, and the Commissioner shall give notice of such declaration by causing copies thereof to be affixed on and near the ground where such fair is holden or proposed to be holden; and after such notice has been affixed for the space of six hours the Commissioner of Police may direct any constable to remove every booth, standing, and tent, and every carriage of whatsoever kind, conveyed to or being upon the ground for the purpose of holding or continuing such fair, and to take into custody every person erecting, pitching, or fixing, or assisting to erect, pitch, or fix, any such booth, standing, or tent; and every person hiring, accompanying, or conveyed in every such carriage, and every person resorting to such ground with any show or instrument of gambling or amusement, and every person convicted before a magistrate of any of the offences aforesaid, shall be liable to a penalty of not more than [level 1]'. (italics supplied)

${ }^{22}$ The Metropolitan Fairs Act 1868, s 4 states: 'All powers conferred by this Act shall be deemed to be in addition to and not in derogation of any other powers conferred by any other Act of Parliament, and any such other powers may be exercised as if this Act had not passed.'

${ }^{23}$ If this Act is repealed, the matter is still covered by the 1839 Act.

${ }^{24}$ See also Halsbury, Laws of England (4th ed), vol 29(2), para 1062 (statutory fairs, ability of the Attorney-General to bring suit). See also County Courts Act 1984, s 15(2)(b) (county court has no jurisdiction rean action concerning title to a fair). See also Halsbury, Statutes (5th ed), para 801 et seq.

${ }^{25}$ See McBain, n 19, pp 287-90. 
- providing instead that any markets (or fairs) regulated thereunder (I suspect there are none) should now be governed by the Food Act 1984 (which Act makes provision for the time and hours of markets, byelaws etc);

- Searching Vessels. Section s 33 allows MPD officers to board vessels on the Thames and creeks. ${ }^{26}$ This police power should be inserted in more modern legislation. Further, this section should be made into general legislation;

- $\quad$ Street Crimes. Sections ss 54 \& 60 specify various street crimes. As previously noted, most of these should have been repealed by the Deregulation Act 2015, sch 23, pt 9. ${ }^{27}$ Further, none of these should be retained if there are not also repeated in the 1847 Act and - since it is asserted that all those still in the 1847 Act should also be repealed (see (c)) - no street crimes in the 1839 Act are worth retaining.

\section{In conclusion, the 1839 Act should be repealed (including all streets crimes contained in it). Sections on carriage routes(ss 52-3) should be placed in general legislation. So too, s 33 (searching vessels).}

\section{(c) Town and Police Clauses Act 1847}

The 1847 Act only applies to urban districts. Various street crimes laid down in the 1847 Act, s 28 were repealed by the Deregulation Act 2015, sch $17 .{ }^{28}$ Thus, the only street crimes left in s 28 are as follows, every person who:

- $\quad$ Dogs - suffers to be at large any unmuzzled ferocious dog, or sets on or urges any dog or other animal to attack, worry, or put in fear any person or animal;

- $\quad$ Furious Driving - rides (or drives) furiously any horse (or carriage), or drives furiously any cattle;

- $\quad$ Discharges Firearm - wantonly discharges any firearm, or throws or discharges any stone or other missile, or makes any bonfire, or throws or sets fire to any firework.

In the case of these:

- Dogs. This crime is no longer required since the first matter is now covered by the Dangerous Dogs Act 1991, s 3 (keeping dogs under proper control). Further, setting a dog (or other animal) on a person is a form of harassment, a distinct crime;

- $\quad$ Furious Driving.It may be noted that causing bodily injury by furious driving is dealt with in the Offences against the Person Act $1861, \mathrm{~s} 35 .^{29}$ This crime (which is, also, likely covered by that of cruelty to animals, in part) is not required. It is to be remembered that the 1847 Act only applies to urban districts. Thus, this is not a crime in the City of London, for example. Further, this crime, anyway, is covered by general legislation - the Highway Act 1835 , s 78 (see (a));

- $\quad$ Firearms etc. Firearms - in respect of unlawful possession of the same is regulated by the criminal law. And, even if lawfully possessed, their discharge is regulated by the civil law (negligence, the reference in the Act to 'wanton' suggests careless discharge or discharge without good reason). Also, by noise abatement requirements. In the case of missiles, today, the law focuses less on the act of throwing and more on the result - whether criminal damage or

\footnotetext{
${ }^{26} v i z$. 'Any superintendent or inspector belonging to the metropolitan police force shall have power, by virtue of his office, to enter at all times, with such constables as he shall think necessary, as well by night as by day, into and upon every ship, boat, or other vessel (not being then actually employed in her Majesty's service) lying in the said river or creeks, or in any dock or docks thereto adjacent, and into every part of every such vessel, for the purpose of inspecting and upon occasion directing the conduct of any constable who may be stationed on board of any such vessel, and of inspecting and observing the conduct of all other persons who shall be employed on board of any such vessel in or about the lading or unlading thereof, as the case may be, and for the purpose of taking all such measures as may be necessary for providing against fire and other accidents, and preserving peace and good order on board of any such vessel, and for the effectual prevention or detection of any felonies or misdemeanours.'

${ }^{27}$ See $\mathrm{n} 9$.

${ }^{28}$ viz. 'In section 28 of the Town Police Clauses Act 1847 (which creates a number of offences) omit the paragraphs beginning - (a)“Every person who exposes for show, hire or sale"; (b)"Every person who slaughters or dresses any cattle"; (c)"Every person having the care of any waggon, cart or carriage"; (d)"Every person who causes any public carriage, sledge, truck, or barrow"; (e) "Every person who causes any tree or timber or iron beam"; (f) "Every person who leads or rides any horse or other animal"; (g) "Every person who places or leaves any furniture"; (h)"Every person who places, hangs up, or otherwise exposes to sale"; (i)“Every person who rolls or carries any cask"; (j)“Every person who places any line, cord or pole"; (k)"Every person who publicly offers for sale or distribution,";(1)"Every person who wilfully and wantonly disturbs any inhabitant"; (m)"Every person who flies any kite,"; (n)"Every person who cleanses, hoops, fires, washes, or scalds"; (o)"Every person who throws or lays down any stones"; (p)“"Every person who beats or shakes any carpet"; (q)"Every person who fixes or places any flower-pot or box"; (r)“"Every person who throws from the roof"; (s)“Every occupier of any house or other building"; (t)"Every person who leaves open any vault or cellar"; (u) "Every person who throws or lays any dirt, litter, or ashes"; (v)“"Every person who keeps any pigstye".

${ }_{29}$ viz. 'Whosoever, having the charge of any carriage or vehicle, shall by wanton or furious driving or racing, or other wilful misconduct, or by wilful neglect, do or cause to be done any bodily harm to any person whatsoever, shall be guilty of a misdemeanor...'
} 
injury to the person. This is more appropriate. As for fires and firearms, general legislation - the Highways Act 1980, s 161 applies ${ }^{30}$ as well as the Explosives Act 1875, s $80 .^{31}$

It is asserted that these crimes are not required. Other provisions of the 1847 Act deal with:(a) regulations on street processions; ${ }^{32}$ and (b) hackney carriages. ${ }^{33}$ These shouldnow be placed - in the case of (a) - in the Highways Act 1980. And - in the case of (b) - in more modern general legislation (see also 5).

\section{In conclusion, the 1847 Act should be repealed (including all street crimes contained in it). Sections on street processions and hackney carriages should be placed in general legislation.}

\section{(d) Metropolitan Police Act 1864}

This Act, s 1, concerns noise nuisance by street musicians in the City of London and the MPD. It states:

any householder within the [MPD], personally, or by his servant, or by any police constable, may require any street musician or street singer to depart from the neighbourhood of the house of such householder, on account of his illness or on account of the interruption of the ordinary occupations or pursuits of any inmate of such house, or for other reasonable or sufficient cause...'

This street crime is very limited in scope in that it applies to the MPD. Thus, it would not be a crime in the City of London or urban districts. Also, there appears to have only been one (old) case. ${ }^{34}$ Today, there is more modern legislation concerning noise abatement which focuses on the noise, without specific reasons having to be given.

\section{In conclusion, the Metropolitan Police Act 1864 should be repealed.}

\section{(e) Metropolitan Streets Act 1867 \& Metropolitan Streets Amendment Act 1867}

The extant sections of the first Act only cover a limited area of London. ${ }^{35}$ It states:

- $\quad$ s 6 (Deposit of Goods in Streets \& Footways). 'No goods or other articles shall be allowed to rest on any footway or other part of a street ${ }^{36}$ within the...limits of this Act, or be otherwise allowed to cause obstruction or inconvenience to the passage of the public, for a longer time than may be absolutely necessary for loading or unloading such goods or other articles. [penalty, level 3].' Section 6 was amended by the Metropolitan Street Amendment Act 1867, s 1 which states that it: ' shall not apply to costermongers, street hawkers, or itinerant traders, so long as they carry on their business in accordance with the regulations from time to time made by the Commissioner of Police, with the approval of the Secretary of State.';

- $\quad$ s 7 (Cattle). 'No person shall drive or conduct any cattle ${ }^{37}$ through any street within the...limits of this Act between the hours of ten in the morning and seven in the evening, except with the permission of the Commissioner of the Police [penalty, level 1].';

- $\quad$ s 9 (Adverts). 'No picture, print, board, placard, or notice, except in such form and manner as may be approved of by the Commissioner of Police, shall, by way of advertisement, be carried or distributed in any street within the... limits of this Act by any person riding in any vehicle, or on horseback, or being on foot... This section shall not apply to the sale of newspapers. [penalty, level 1].

These sections - which appear to have no caselaw, save for section $9^{38}$ - apply to a limited area of London. It is asserted that s 6 (if required) should be inserted into the Highways Act 1980 since it relates to obstruction of the highway (which includes a street). Section 7 is not required since there are no live cattle (animal) markets within the 'limits of the Act' now. It would also constitute an obstruction of the highway, as would section 9. Thus, these sections, which only apply to a limited area of London, are not required and - if determined otherwise should now be contained in general legislation (i.e. no cattle, adverts etc save in accordance with local byelaws).

\footnotetext{
${ }^{30}$ viz. '(2) If a person without lawful authority or excuse - (a) lights any fire on or over a highway which consists of or comprises a carriageway; or(b) discharges any firearm or firework within 50 feet of the centre of such a highway, and in consequence a user of the highway is injured, interrupted or endangered....[penalty, level 3].'

31 viz. 'If any person throw, cast, or fire any fireworks on or into any highway, street, thoroughfare, road or public place.'

${ }^{32}$ See 1847 Act, ss $21 \& 23$.

${ }^{33}$ Ibid, ss 37- 68 .

${ }^{34}$ Shields $v$ Howard [1897] 1 QB 84, per Grantham J at p 85 'unless there is some such cause, the street musician or singer, in refusing to obey the householder's requirement, commits no offence.' .

${ }^{35}$ The Act, s 3, 'The following expressions for the purposes of this Act shall, unless the context requires a different construction, have the meanings herein-after assigned to them; that is to say,...." the limits of this Act" means - (a) the City of London; (b) the area enclosed in a circle of which the centre is Charing Cross, and the radii are six miles in length as measured in a straight line from Charing Cross.'

${ }^{36}$ Ibid, "Street" shall include any highway or other public place, whether a thoroughfare or not;...'

${ }^{37}$ Ibid.'The word "cattle" shall include bull, ox, cow, heifer, calf, sheep, goats, and swine, also horses, mules, and asses, when led in a string or loose."

${ }^{38}$ Fulton v Kelly (1889) 5 TLR 325 (lack of disapproval is sufficient).
} 
In conclusion, this Act should be repealed. However, if ss 6, 7 and 9 are thought to be still required, they should be inserted into the Highways Act 1980.

\section{(f) Town Police Clauses Act 1889}

This $\mathrm{Act}^{39}$ - which is construed together with the 1847 Act, only applies to a horse-drawn omnibus ${ }^{40}$ (with the exception of s 5). ${ }^{41}$ Thus, it is obsolete, as Halsbury notes. ${ }^{42}$

In conclusion, this Act should be repealed - save for section 5 which refers to the 1847 Act and it should be placed therein, if still required.

\section{LEGISLATION - RAILWAY \& TRAM CRIMES}

There are various pieces of legislation pre-1890 extant which relate to railways, viz.

- $\quad$ Highway (Railway Crossings) Act 1839;

- Railway Regulation Act 1840;

- Railway Regulation Act 1842;

- Railways Clauses Consolidation Act 1845;

- $\quad$ Locomotive Act 1861 (spent);

- Railways Clauses Act 1863;

- Railway Companies Act 1867;

- Regulation of Railways Act 1868;

- Tramways Act 1870;

- Regulation of Railways Act 1873 (spent);

- $\quad$ Railway and Canal Traffic Act 1888;

- Regulation of Railways Act 1889.

Only some of these Acts contain crimes, viz:

\section{(a) Railway Regulation Act 1840}

This Act, section16, makes it a crime to: (a) obstruct a railway officer; (b) trespass on the railway. It states:

If any person shall wilfully [i.e. intentionally] obstruct or impede any officer or agent of any railway company in the execution of his duty upon any railway, or upon or in any of the stations or other works or premises connected therewith, or if any person shall wilfully trespass upon any railway, or any of the stations or other works or premises connected therewith etc.... [penalty, level 1].

\section{This Act should be consolidated with later Railway Acts and the wording of these crimes modernised.}

\section{(b) Railways Clauses Consolidation Act 1845}

This Act contains various minor crimes, viz:

- Section 23 - interrupting gas or water supply; ${ }^{43}$ s 24 - interrupting construction of the railway; ${ }^{44}$ s 54 - not substituting a road; ${ }^{45} \mathrm{~s} 57$ - not restoring a road; ${ }^{46} \mathrm{~s} 75$ - omitting to fasten gates for the owner of adjoining lands; ${ }^{47}$

\footnotetext{
${ }^{39}$ It is also incorporated with the Public Health Act 1875. Thus, s 2 provides: 'This Act shall be construed as one with the principal Act [i.e. the 1847 Act], and the expression "this Act" in the principal Act shall be construed to mean the principal Act as amended by this Act. (2) This Act shall be deemed to be incorporated with the Public Health Act, 1875, by [s 171] of that Act.'

${ }^{40}$ Town Police Clauses Act 1889, s 3.

${ }^{41}$ Ibid, s 5 'Any licence may be granted under the principal Act [i.e. Town Police Clauses Act 1847, s 37] to continue in force for such less period than one year as the Commissioners may think fit, and shall specify in the licence.' This section 5 should be repealed and the 1847 Act, s 43 amended to cover it, if required.

${ }^{42}$ Halsbury, Statutes, vol 36 (Application of Act).

43 'If by any such operations as aforesaid the company shall interrupt the supply of any water or gas...[penalty $£ 20$ for every day supply interrupted].'

44 'If any person wilfully obstruct any person acting under the authority of the company in the lawful exercise of their power in setting out the line of the railway, or pull up or remove any poles or stakes driven into the ground for the purpose of so setting out the line of the railway, or deface or destroy any marks made for the same purpose [penalty, level 1].'

45 'If the company do not cause another sufficient road to be so made before they interfere with any such existing road as aforesaid, they shall forfeit [£20 for every day]. '

46 'If any such road be not so restored, or the substituted road so completed as aforesaid, within the periods herein or in the special Act fixed for that purpose, the company shall forfeit [ $£ 5$ for every day].'

47 'If any person omit to shut and fasten any gate or [to lower any barrier] set up at either side of the railway for the accommodation of the owners or occupiers of the adjoining lands as soon as he and the carriage, cattle, or other animals under his care have passed through the same [penalty, level 3].'
} 
s 103 - a passenger refusing to leave a train when it reaches its destination for him; ${ }^{48} \mathrm{~s} 116$ - using improper engines; ${ }^{49} \mathrm{~S} 119$ - using improper carriages; ${ }^{50} \mathrm{~s} 144$ - defacing byelaw boards; ${ }^{51} \mathrm{~s} 163$ - railway company failing to keep a copy of any Special Act; ${ }^{52}$

- Obsolete Crimes. It is asserted that ss $23,24,54,57,116 \& 119$ should be repealed. They do not need to be treated as crimes - the issue is better dealt with as a civil matter (negligence or breach of contract,if not otherwise dealt with under other legislation relating to utilities). Further, ss $116 \& 119$ do not apply to modern rolling stock. Section 144 should also be repealed and the crime be that of causing criminal damage. Section 163 should be repealed. It is unnecessary to make this a crime;

- $\quad$ Refusing to Leave Train. As for s 103, the penalty is low, it is limited in extent (only applying when a person reaches his destination) and it is asserted that - in modern times - the crime of trespass would be more appropriate in any case (see also (a) and (f) which deal with trespass). There appear to have been no cases and this Act applied before British Transport Police were created. Thus, this crime should be repealed. Today, if a passenger refuses to quit the train at his destination - but is not committing any other crime (assault, harassment etc) - he can be charged for the excess. If committing another crime, he can be removed for it;

- $\quad$ Not Shutting Gate. As for s 75, most (if not all) railway gates are automated today and not raised or lowered by hand. Further, this crime was intended only to be for the benefit of occupiers of adjoining lands in respect of their carriage (car) or animals passing through and not for negligence generally in omitting to close a gate. It is not required.

\section{This Act should be consolidated with later Railway Acts and the wording of any of these crimes - if deemed to be worthy of retention - should be modernised.}

\section{(c) Malicious Damage Act 1861}

This makes it a crime to intentionally: (a) place (or throw) objects on the line; (b) remove (or displace) rails or other railway matter; (c) interfere with points, signals or other machinery; (d) do anything to obstruct etc. any engine or carriage. Thus:

- s 35 'Whosoever shall unlawfully and maliciously cut, place, cast, or throw upon or across any railway any wood, stone, or other matter or thing, or shall unlawfully and maliciously take up, remove, or displace any rail, sleeper, or other matter or thing belonging to any railway, or shall unlawfully and maliciously turn, move, or divert any points or other machinery belonging to any railway, or shall unlawfully and maliciously make or show, hide or remove, any signal or light upon or near to any railway, or shall unlawfully and maliciously do or cause to be done any other matter or thing, with intent, in any of the cases aforesaid, to obstruct, upset, overthrow, injure, or destroy any engine, tender, carriage, or truck using such railway[penalty, imprisonment];'

- $\quad$ s 36 'Whosoever, by any unlawful act, or by any wilful omission or neglect, shall obstruct or cause to be obstructed any engine or carriage using any railway, or shall aid or assist therein [penalty, imprisonment not exceeding 2 years].'

These crimes are also in the Offences Against the Person Act 1861 ('OPA 1861') see (d) below, with the proviso that the intent be to endanger passengers.

In conclusion, this Act should be repealed. ${ }^{53}$

\footnotetext{
${ }^{48}$ 'If any person knowingly and wilfully refuse or neglect, on arriving at the point to which he has paid his fare, to quit such carriage [penalty, level 1].'

${ }^{49}$ 'If any person, whether the owner or other person having the care thereof, bring or use upon the railway any locomotive or other engine, or any moving power without having first obtained such certificate of approval as aforesaid, or if, after notice given by the company to remove any such engine from the railway, such person do not forthwith remove the same, or if, after notice given by the company not to use any such engine on the railway, such person do so use such engine without having first repaired the same to the satisfaction of the company and obtained such certificate of approval [penalty, level 2] ... Nothing in this section shall apply to the bringing or use of any rolling stock on track comprised in a network, the person having the management of which for the time being is the holder of a network licence; and in this section "rolling stock", "track", "network" and "holder of a network licence" shall be construed in accordance with Part I of the Railways Act 1993.]'

${ }_{50}$ 'If any carriage, not being of such construction or in such condition as the regulations of the company for the time being require, be made to pass or be upon any part of the railway (except as aforesaid,) the owner thereof, or any person having for the time being the charge of such carriage,...[penalty, level 1]... Nothing in this section shall apply to the bringing or use of any rolling stock on track comprised in a network, the person having the management of which for the time being is the holder of a network licence; and in this section "rolling stock", "track", "network" and "holder of a network licence" shall be construed in accordance with Part I of the Railways Act 1993.]'

${ }^{51}$ 'If any person pull down or injure any board put up or affixed [for the purpose of publishing any byelaw of the company or any penalty imposed by this or the special Act], or shall obliterate any of the letters or figures thereon [penalty, level 1. Also, the expenses of repair].'

52 'If the company shall fail to keep or deposit as hereinbefore mentioned, any of the said copies of the special Act [penalty, level 2 and $£ 5$ for every day during which such copy not be kept or deposited].' Section 2 states: 'The expression "the special Act" used in this Act shall be construed to mean any Act which shall be hereafter passed authorizing the construction of a railway, and with which this Act shall be so incorporated as aforesaid...'
} 


\section{(d) $\underline{\text { OPA } 1861}$}

This Act makes the following crimes: with intent to endanger passengers, unlawfully and maliciously to: (a) place (or throw) objects on the railway line; (b) remove (or displace) rails or other railway matter; (c) interfere with points, signals or other machinery; (d) do (or cause to be done) anything else. Also, (e) with intent to injure or endanger passengers - unlawfully or maliciously to throw (or cause to fall) objects at a train. Also, (f) by unlawful act (or omission) to endanger passengers. Thus, it states:

- s 32 'Whosoever shall unlawfully and maliciously put or throw upon or across any railway any wood, stone, or other matter or thing, or shall unlawfully and maliciously take up, remove, or displace any rail, sleeper, or other matter or thing belonging to any railway, or shall unlawfully and maliciously turn, move, or divert any points or other machinery belonging to any railway, or shall unlawfully and maliciously make or show, hide or remove, any signal or light upon or near to any railway, or shall unlawfully and maliciously do or cause to be done any other matter or thing, with intent, in any of the cases aforesaid, to endanger the safety of any person travelling or being upon such railway...[penalty, imprisonment]';

- $\quad$ s 33. 'Whosoever shall unlawfully and maliciously throw, or cause to fall or strike, at, against, into, or upon any engine, tender, carriage, or truck used upon any railway, any wood, stone, or other matter or thing, with intent to injure or endanger the safety of any person being in or upon such engine, tender, carriage, or truck, or in or upon any other engine, tender, carriage, or truck of any train of which such first-mentioned engine, tender, carriage, or truck shall form part...[penalty, imprisonment]';

- $\quad$ s 34. 'Whosoever, by any unlawful act, or by any wilful omission or neglect, shall endanger or cause to be endangered the safety of any person conveyed or being in or upon a railway, or shall aid or assist therein [penalty, imprisonment not exceeding two years]'.

In a report on Reform of Offences against the Person (Law Com, no 361) in 2015, the Law Commission recommended these crimes be replaced by a more modern one - that of intentionally (or recklessly) causing danger to a person. ${ }^{54}$ One would agree (it should also cover trams, see (e) below).

\section{In conclusion, these crimes should be repealed.}

\section{(e) Tramways Act 1870}

This Act - which needs to be modernised - provides, in section 47, that penalties may be imposed for breaches of the byelaws. It also makes the following, crimes:

- $\quad$ s 49 (Penalty for obstruction of promoters in laying out tramway).'If any person wilfully obstructs any person acting under the authority of any promoters in the lawful exercise of their powers in setting out or making, forming, laying down, repairing, or renewing a tramway, or defaces or destroys any mark made for the purposes of setting out the line of tramway, or damages or destroys any property of any promoters, lessees, or licensees...[penalty, level 1];'

- $\quad$ s 50 (Penalty for wilful injury or obstruction to tramway) 'If any person, without lawful excuse (the proof whereof shall lie on him), wilfully does any of the following things; (namely,) Interferes with, removes, or alters any part of a tramway or of the works connected therewith; Places or throws any stones, dirt, wood, refuse, or other material on any part of a tramway; Does or causes to be done anything in such manner as to obstruct any carriage using a tramway, or to endanger the lives of persons therein or thereon; Or knowingly aids or assists in the doing of any such thing...[penalty, level 1]';

- $\quad$ S 51 (Penalty on passengers practising frauds on the promoter). 'If any person travelling or having travelled in any carriage on any tramway avoids or attempts to avoid payment of his fare, or if any person having paid his fare for a certain distance knowingly and wilfully proceeds in any such carriage beyond such distance, and does not pay the additional fare for the additional distance, or attempts to avoid payment thereof, or if any person knowingly and wilfully refuses or neglects on arriving at the point to which he has paid his fare to quit such carriage...[penalty, level 1]';

- S 53 (Penalty for bringing dangerous goods on the tramway). 'No person shall be entitled to carry or to require to be carried on any tramway any goods which may be of a dangerous nature; and if any person send by any tramway any such goods without distinctly marking their nature on the outside of the package containing the same, or otherwise giving notice in writing to the book-keeper or other servant with whom the same are left at the time of such sending....[penalty, level 2]';

- $\quad$ S 55 (Penalty for persons using tramways with carriages with flange wheels, $\&$ c). 'If any person (except under a lease from or by agreement with the promoters, or under licence from the Board of Trade, as by this Act provided) uses a tramway or any part thereof with carriages having flange wheels or other wheels suitable only to run on the rail of such tramway...[penalty, level 2].'

It is asserted that s 49 should be repealed and the general law on trespass, harassment and criminal damage apply instead. In respect of s 53, legislation on dangerous goods (firearms, explosive etc) should apply as well as civil remedies for damage (in any case, this minor crime does not seem to be replicated in railway

\footnotetext{
${ }^{53}$ The only other sections of the Act extant are: s 58 ( malice against the owner of the property unnecessary) \& s 78 (offences committed within the jurisdiction of the Admiralty). The latter is spent since there are no sections in the Act now relating to admiralty matters.

${ }^{54}$ Law Commission, Reform of Offences against the Person (2015), pp 178-9, 216.
} 
legislation).Thus, it should be repealed. As for s 55, it is obsolete. The remaining sections should also be repealed and the crimes applying to railways in respect of - obstructing officers, trespass, causing danger to a person and avoiding payment of the fare - be extended to cover trams. This, manifestly, would make good sense.

\section{In conclusion, the crimes in this Act should be repealed and the crimes applicable to trains be extended to} cover trams.

\section{(f) $\underline{\text { Regulation of Railways Act } 1868}$}

This Act makes it a crime to trespass on the railway line:

S 23 'If any person shall be or pass upon any railway, except for the purpose of crossing the same at any authorized crossing, after having once received warning by the company which works such railway, or by any of their agents or servants, not to go or pass thereon [penalty, level 1]'.

The Railway Regulation Act 1840 (see (a)) also deals with trespass on the railway.Thus, it is asserted this, more specific, crime is not required. There appears to be no caselaw.

\section{In conclusion, the crime in this Act should be repealed.}

\section{(g) $\underline{\text { Regulation of Railways Act } 1889}$}

This Act makes it a crime to fail to pay the train fare. Thus:

S 5(1) 'Every passenger by a railway shall, on request by an officer or servant of a railway company, either produce, and if so requested deliver up, a ticket showing that his fare is paid, or pay his fare from the place whence he started, or give the officer or servant his name and address..

(3) If any person - (a) travels or attempts to travel on a railway without having previously paid his fare, and with intent to avoid payment thereof; or (b) having paid his fare for a certain distance, knowingly and wilfully proceeds by train beyond that distance without previously paying the additional fare for the additional distance, and with intent to avoid payment thereof; or (c) having failed to pay his fare, gives in reply to a request by an officer of a railway company a false name or address, they shall be liable on summary conviction to a fine [penalty, level 3]..or in the discretion of the court to imprisonment for a term not exceeding [3 months]....

This section should be modernised and should also apply to trams (assuming the Tramways Act 1870 is still required, see (e)).

\section{(h) Conclusion}

The Law Commission should request the DfT to consolidate the above railway and tram legislation into a modern Act. It would seem the only crimes needing to be retained as 'railway' specific - are, to:

- $\quad$ intentionally obstruct a railway (or tramway) employee (see (a));

- $\quad$ intentionally (or recklessly) cause danger to a person on a railway (or tramway) or to a passenger (see (d));

- trespass on a railway (or tramway)(see (a));

- $\quad$ fail to pay the requisite fare (see (g));

\section{LEGISLATION - CANALS, SHIPPING, PORTS \& HARBOURS CRIMES}

In respect of legislation extant pre-1890:

- Canals. There are: Canal Carriers Act 1845, Canal (Carriers) Act 1847, Railway and Canal Traffic Act 1888 and the Canals Protection (London) Act 1898. However, they stipulate no minor crimes;

- $\quad$ Shipping. There are: Merchant Shipping Law Amendment Act 1853 and the Merchant Shipping Repeal Act 1854. However, they stipulate no minor crimes. They are also obsolete;

\footnotetext{
${ }^{55}$ See also s 5(2) 'If a passenger having failed either to produce, or if requested to deliver up, a ticket showing that his fare is paid, or to pay his fare, refuses [or fails] on request by an officer or servant of a railway company, to give his name and address, any officer of the company... may detain him until he can be conveniently brought before some justice or otherwise discharged by due course of law.' Also, $\mathrm{s}$ 5(4) The liability of an offender to punishment under this section shall not prejudice the recovery of any fare payable by him. [ (5) In this section - (a) "railway company" includes an operator of a train, and (b) "operator", in relation to a train, means the person having the management of that train for the time being]'.
} 
- $\quad$ Harbours, Ports, Dockyards. There are the Harbours, Docks and Piers Clauses Act 1847, Harbours and Passing Tolls etc Act 1861, Harbours Transfer Act 1862 and the Dockyards, Ports Regulation Act 1865. The Act of 1847 contains (but the others do not) a number of minor crimes viz. in respect of:

(a) section 15 (not providing a watch (customs) house); ${ }^{56}$

(b) section17(not providing a lifeboat); ${ }^{57}$

(c) section 19(not providing a tide guage or barometer); 58

(d) section 38(masters giving no account (or notice) re cargo); ${ }^{59}$

(e) section 43(evading payment of rates) ${ }^{60}$

(f) section 53 (not complying with the directions of the harbour master) $;^{61}$

(g) section 54 (misbehaviour of harbour master), ${ }^{62}$

(h) section 55 (bribery); ${ }^{63}$

(i) section 62 (wilful cutting of moorings); ${ }^{64}$

(j) section 63 (placing vessels near the harbour entrance without permission); ${ }^{65}$

(k) section 67 (wharfinger giving undue preference in loading/unloading); ${ }^{66}$

(l) section 71 (provisions for crimes re combustible material, gunsetc); ${ }^{67}$

(m) section 73 (throwing ballast into the harbour). ${ }^{68}$

\footnotetext{
${ }^{56} v i z$. 'If at any time such watch-house or boat-house or such huts or weighing materials shall be out of repair, or not provided as required by the said commissioners, and notice thereof be given to the undertakers, they shall repair or provide the same to the satisfaction of the said commissioners within three months after such notice, or in default thereof shall forfeit the sum of one hundred pounds for every month during which such watch-house, boat-house, huts, or weighing materials shall continue out of repair or be not provided..." See also s 14.

${ }^{57} v i z$. 'The undertakers shall be liable to a penalty not exceeding two pounds for every twenty-four hours during which the said life-boat, mortar, and rockets, or any of them, or the tackle belonging thereto, shall not be provided or maintained and stationed as aforesaid.' See also s 16.
}

S 16 .
${ }_{58}$ viz. 'The undertakers shall be liable to a penalty not exceeding two pounds for every twenty-four hours during which the said selfregistering tide gauge and barometer shall not be provided or maintained, or such account of the wind and weather shall not be kept as aforesaid; and they shall be liable to a penalty not exceeding [level 1] for each month they shall neglect or refuse to send as aforesaid to the Secretary of the Admiralty a full and true account of the daily workings of the said tide gauge and barometer, and of the daily state of the wind and weather.' See also s 18.

${ }^{59} \mathrm{viz}$. 'Every master of a vessel of which the cargo or part of the cargo shall be unshipped within the limits of the harbour, dock, or pier, who shall have failed to deliver or to give any of the particulars in regard to the cargo or the notice in regard to the unshipment thereof hereinbefore required to be delivered or given by such master, or who shall deliver or give any false particulars or notice, shall for every such offence be liable to a penalty not exceeding [level 3].'

${ }^{60} \mathrm{viz}$. 'If the master of any vessel or the owner of any goods evade the payment of the rates payable to the undertakers in respect of such vessel or goods, or any part thereof, he shall pay to them three times the amount of the rates of which he shall so have evaded the payment, and the same shall be recovered from such master or owner respectively in the same manner as penalties imposed by this Act are directed to be recovered, or by action in any court of competent jurisdiction.'

${ }^{61}$ viz. 'The master of every vessel within the harbour or dock, or at or near the pier, or within the prescribed limits, if any, shall regulate such vessel according to the directions of the harbour master, made in conformity with this and the special Act; and any master of a vessel who, after notice of any such direction by the harbour master served upon him, shall not forthwith regulate such vessel according to such direction shall be liable to a penalty not exceeding [level 2].'

${ }^{62} v i z$. 'If any harbour master, or any of his assistants, without reasonable cause, or in an unreasonable or unfair manner, exercise any of the powers or authorities vested in the harbour master by this or the special Act, the person so offending shall for every such offence be liable to a penalty not exceeding [level 1].'

${ }_{63}^{6}$ viz. 'If any person give or offer any sum of money, or any thing whatsoever, by way of reward or bribe to any harbour master or any officer employed in or about the harbour, dock, or pier, for the purpose of gaining an undue preference in the execution of his office, or for the purpose of inducing such harbour master or other officer to do or omit to do anything relating to his office, or if such harbour master or other officer receive any such reward or bribe as aforesaid, every person so offending shall be liable for every such offence to a penalty of [level 2].'

${ }^{64} \mathrm{viz}$ 'Every person, other than the harbour master, who shall wilfully cut, break, or destroy the mooring or fastening of any vessel lying in the harbour or dock, or at or near the pier, shall for every such offence be liable to a penalty not exceeding [level 1].'

${ }^{65}$ viz. 'As soon as the harbour or dock shall be so far completed as to admit vessels to enter therein, no vessel, except with the permission of the harbour master, shall lie or be moored in the entrance of the harbour or dock, or within the prescribed limits; and if the master of any vessel either place it or suffer it to remain in the entrance of the harbour or dock, or within the prescribed limits, without such permission, and do not, on being required so to do by the harbour master, forthwith proceed to remove such vessel, he shall be liable to a penalty not exceeding [level 1], and a further sum of [£1] for every hour that such vessel shall remain within the limits aforesaid, after a reasonable time for removing the same has expired after such requisition.'

${ }^{66} \mathrm{viz}$. 'If any wharfinger or other servant of the undertakers, or any of their lessees, or the servants of such lessees, shall give any undue preference or show any partiality in loading or unloading any goods on any of the quays, wharfs, or other works belonging to the undertakers, the person so offending shall be liable to a penalty not exceeding [level 1].'

${ }^{67} v i z$. 'Every person who shall commit any of the acts following shall be deemed guilty of an offence, and shall for every such offence be liable to a penalty not exceeding [level 1]; (that is to say,) 1. Every person who shall boil or heat any pitch, tar, resin, turpentine, oil, or other combustible matter, in any vessel lying within the harbour or dock, or near the pier, or in any place within the limits of the harbour, dock, or pier, except in such place and in such manner as shall be specially appointed by the undertakers for that purpose: 2 . Every person who shall have or cause to be had any fire or lighted candle or lamp in any vessel within the harbour or dock, or at or near the pier, except with the permission of the harbour master: 3. Every person who shall have or cause to be had any fire, candle, or lamp lighted within any of the docks or the works belonging to the same, except at such times and in such manner as shall be permitted by the byelaws of the undertakers: 4. Every person who shall bring any loaded gun on the quays or works of the harbour or dock, or on the pier, or shall have or suffer to remain any loaded gun in any vessel in the harbour or dock, or at or near the pier.'

${ }^{68}$ viz. 'Every person who shall throw or put any ballast, earth, ashes, stones, or other thing into the harbour or dock shall for every such offence be liable to a penalty not exceeding [level 1].' 
It is asserted that, at least, some of these are obsolete and not required, such as (a)-(c). Others - such as bribery and cutting moorings (see (h) and (i)) - are better covered by the modern legislation on bribery and criminal damage which is more severe. Finally, those still worthy of retention should be modernised.

In conclusion, the Law Commission should ask the relevant Government departments (for example, Defra deals with canals) to consolidate the above legislation as well as confirm the appropriateness of repealing obsolete crimes.

\section{LEGISLATION - HACKNEY CARRIAGE CRIMES}

There are a number of pieces of legislation pre-1890 which relate to London hackney carriages. These comprise the:

- London Hackney Carriages Acts of $1831,1843,1850$ and 1853 as well as the 1847 Act (i.e. the Town Police Clauses Act 1847, see 2(c)) and the Metropolitan Public Carriage Act 1869. There is also the Town Police Clauses Act 1889 which applies to horse-drawn buses. However, it is obsolete;

- $\quad$ This (very) antiquated legislation regulates London's black cabs, with fines for various breaches of the same. At present, the regulating authority is Transport for London ('TfL').

This material should not be in primary legislation but in byelaws - not least because of the problems of amending it. It should also be revised in the light of the Local Government (Miscellaneous Provisions) Act 1976, ss 45-80 which deal with hackney carriages not in London. In short, the Highways Act 1980 should provide that the DfT - and TfL in the case of London - may issue byelaws for the regulation of taxis (and older equivalents) ${ }^{69}$ the same to include penalties for infractions up to a stated maximum level on the standard scale.

\section{In conclusion, the Law Commission should request that statutory provision be made for the DfT (and TfL) to issue byelaws governing taxis and carriages. ${ }^{70}$}

\section{LEGISLATION - OTHER PRE-1890 CRIMES}

If one considers the remaining legislation extant, pre-1890, there are few minor crimes set out in it. However, the following may be noted:

- Markets \& Fairs. This legislation comprises the Markets and Fairs Clauses Act 1847, Metropolitan Fairs Act 1868, Fairs Acts $1871 \& 1873$ and the Markets and Fairs (Weighing of Cattle) Act 1887 (obsolete). These should be consolidated and modernised generally. However, the Markets and Fairs Clauses Act 1847 contains crimes in respect of:

s 13 (sales other than in markets prohibited) ${ }^{71}$

s 16 (assault and obstructing a market or fair keeper) ${ }^{72}$

s 19 (slaughtering cattle) ${ }^{73}$

s 37 (taking a greater toll than authorised) $;^{74}$

s 40 (assault and obstructing a collector of rents), $;^{75}$

s 59 (failing to keep copy of the Special Act). ${ }^{76}$

\footnotetext{
${ }^{69}$ Horse drawn carriages (i.e. hackney carriages) are still possible in London. For the history of vehicles in London, see GS McBain, Time to Abolish the Common Carrier [2005] JBL, Sept. pp 548-52.

${ }^{70}$ Alternatively, matters could be set out in a SI.

${ }^{71}$ viz. 'After the market place is opened for public use every person other than a licensed hawker who shall sell or expose for sale in any place within the prescribed limits, except in his own dwelling place or shop, any articles in respect of which tolls are by the special Act authorized to be taken in the market [penalty, level 1].'

${ }^{72}$ viz. 'Every person who shall assault or obstruct any person appointed by the undertakers to superintend the market or fair, or to keep order therein, whilst in the execution of his duty [penalty, level 1].'

${ }_{73}$ viz. 'After the expiration of ten days from the publication and posting of such notice no person shall slaughter any cattle or dress any carcase for sale as human food or food of man in any place within the limits of the special Act other than a slaughter-house which was in use as such before and at the time of the passing of the special Act, and has so continued ever since, or the slaughter-houses made in pursuance of this and the special Act; and every person who shall after such notice as aforesaid, slaughter any such cattle or dress for sale any such carcase within the limits of the special Act in any place other than one of such slaughter-houses [penalty, level 1].'

${ }^{74} v \mathrm{iz}$. 'Every person who shall demand or receive a greater toll than that authorized to be taken under the provisions of this or the special Act [penalty, level 1].'

${ }^{75}$ viz. 'every person who shall assault or obstruct any person authorized to collect any stallage, rent, or toll authorized by this or the special Act [penalty, level 1].'

${ }^{76}$ viz. 'If the undertakers fail to keep or deposit, as herein-before mentioned, any of the said copies of the special Act [level 2, also $£ 5$ for every day afterwards during which such copy not kept or deposited].'
} 
Cattle are not slaughtered at markets and fairs today. Thus, s 19 is not required. It is asserted that ss 16 and 37 are not needed as crimes since the general law on assault and battery should apply. The law on fairs and markets (which are treated the same as fairs in modern times) is antiquated and should be modernised by the Law Commission employing an expert to consider it. It may also be that the Markets and Fairs Clauses Act 1847 is no longer required since there do not appear to be any markets or fairs in England and Wales now operating pursuant to a Crown grant or local legislation. Rather, all seem to be governed by the Food Act $1984,7^{77}$

- $\quad$ Water. This legislation comprises the Waterworks Clauses Act 1847, Metropolis Water Act 1852, Waterworks Clauses Act 1863 (obsolete), Metropolis Water Act 1871, Metropolis Management (Thames Water Prevention of Floods) Amendment Act 1879, Water Rate Definition Act 1885, Metropolis Water Act 1897, District Councils (Water Supply Facilities) Act 1897, Metropolis Water Act 1902, Metropolitan Water Board (Charges) Act 1907, and the Metropolitan Water Board (Charges) Act 1921. These Acts should be consolidated. Those in italics contain various minor crimes;

- $\quad$ Town Improvements Clauses Act 1847. Section 215 imposes a penalty on a failing to keep a copy of the Special Act. $^{78}$ It is not required;

- $\quad$ Commissioners Clauses Act 1847. Section s 111 imposes a penalty on a failing to keep a copy of the Special Act. ${ }^{79}$ It is not required;

- $\quad \underline{P a r k s .}$ These comprise the Metropolis Management Act 1855 (s 239), Town Gardens Protection Act 1863 and the Parks Regulation Act 1872. The Act of 1863, section 5, makes it a crime to injure a garden within the terms of the Act. ${ }^{80}$ The Parks Regulation Act 1872, s 6 makes it a crime to assault a park constable. ${ }^{81}$ It is asserted the general law on assault and battery should apply today and that this section be repealed (or that the park keeper be treated as a police constable, when undertaking his duty);

- Companies. These comprise the Companies Clauses Consolidation Acts 1845 and 1888 and the Companies Clauses Acts 1863 and 1869. It should be determined whether these are still required. In any case, the Companies Clauses Consolidation Act 1845, s 162 (it imposes a penalty for not keeping a copy of the Special Act), ${ }^{82}$ should be repealed.

In conclusion, the Law Commission should request an expert be appointed to review the law on: (a) fairs and markets; and (b) early company legislation. Also, for the relevant Government department to consolidate the law on water.

\section{POSITION FROM 1890-1970 - CRIME ACTS}

The position as to criminal legislation, post-1890, is much simpler. There is no need for the Law Commission to analyse this legislation, with the exception of one or two Acts which are manifestly obsolete. ${ }^{83}$ Instead, all this legislation can be consolidated into 4 Crime Acts ('crime' is a shorter - and more accurate - word than 'offence'), dealing with the following:

- Sex Crimes. The consolidating Act is the Sexual Offences Act 2003. Other legislation on sex crimes, ${ }^{84}$ should now be consolidated with it, into one Act;

\footnotetext{
${ }^{77}$ See 2(b).

${ }^{78}$ viz. 'If the commissioners shall fail to keep or deposit, as herein-before mentioned, any of the said copies of the special Act [penalty, level 2 , also $£ 5$ for every day afterwards during which such copy not kept or deposited].'

79
viz. 'The commissioners shall at all times after the expiration of six months after the passing of the special Act keep in their principal office of business a copy of the special Act, printed by the printers to her Majesty, or some of them, and shall also within the space of such six months [deposit in the office of the clerk of the peace in England or Ireland, and of the sheriff clerk in Scotland, of the county in which the undertaking is situate][deposit in the office of the chief clerk], a copy of such special Act, so printed as aforesaid; and the said clerk of the peace and sheriff clerk respectively shall receive, and they and the commissioners respectively shall keep, the said copies of the special Act, and shall permit all persons interested to inspect the same, and make extracts or copies therefrom, in the like manner, and upon the like terms, and under the like penalty for default, as is provided in the case of certain plans and sections by the Parliamentary Documents Deposit Act 1837."

${ }^{80} \mathrm{viz}$. 'Any person who throws any rubbish into any such garden, or trespasses therein, or gets over the railings or fence, or steals or damages the flowers or plants, or commits any nuisance therein [level 1 or 14 days imprisonment]... and in case it shall be necessary to state in any proceedings the ownership of the property of such garden, flowers, or plants, it shall be sufficient to describe the same as the property of the committee by the name of $A . B$. and others.'

${ }^{81}$ viz. 'Where any person is convicted of an assault on any [park constable] when in the execution of his duty, [level 2 or to be imprisoned for term not exceeding 6 months].'

${ }^{82}$ viz 'If the company shall fail to keep or deposit as herein-before mentioned any of the said copies of the special Act [£20 for every offence, and also $£ 5$ for every day afterwards during which copy not kept or deposited].'

${ }^{83}$ viz. Aliens Restriction (Amendment) Act 1919, s 3, Incitement to Disaffection Act 1934, Common Informers Act 1951 (spent). See Appendix B.

${ }^{84}$ viz. (a) Children and Young Persons Act 1933, s 3 (children in brothels); (b) Children and Young Persons (Harmful Publications) Act 1955, ss1-4 (harmful publications); (c) Sexual Offences Act 1956, ss 33-7 (brothels); (d) Street Offences Act 1959, ss 1-1A (loitering or
} 
- $\quad$ Public Order Crimes. Acts relating to public should be consolidated into one Act ${ }^{85}$ together with legislation on: (a) alcohol; ${ }^{86}$ (b) fireworks; ${ }^{87}$ (c) vehicles; ${ }^{88}$ (d) sporting events (including football); ${ }^{89}$ (e) drugs; ${ }^{90}$ (f) offensive weapons; ${ }^{91}$ (g) firearms; ${ }^{92}$ (h) explosives $;{ }^{93}$ (i) terrorism; $;{ }^{94}$

- $\quad$ Crimes against the Person. Acts on crimes against the person should now be consolidated into one Act. These include crimes relating to: (a) homicide, suicide and manslaughter; ${ }^{95}$ (b) torture and mutilation; ${ }^{96}$ (c) hostages and slavery; ${ }^{97}$ (d) other offences against the person; ${ }^{98}$ (e) harassment and intimidation; ${ }^{99}$ (f) children; ${ }^{100}$ and $(\mathrm{g}$ ) attempts, conspiracy, incitement, assisting and concealing; ${ }^{101}$

- $\quad$ Financial \& Property Crimes. Legislation on financial, ${ }^{102}$ and property, ${ }^{103}$ crimes should be consolidated into one Act.

In conclusion, all criminal legislation should be placed in 4 Crime Acts. This is perfectly possible - and simple - providing obsolete material is removed.

soliciting); (e) Obscene Publications Act 1959, ss 1-4 (publications); (f) Obscene Publications Act 1964, ss 1-2 (publications); (g) Sexual Offences Act 1967, s 6 (homosexual brothels); (h) Theatres Act 1968, ss 2,3, 8 (obscene plays); (i) Protection of Children Act 1978, ss 1-7 (images); (j) Indecent Displays (Control) Act 1981, ss 1-4 (indecent displays); (k) Criminal Justice Act 1988, ss 160 \&160A (images); (1) Sexual Offences (Amendment) Act 1992, ss 1-6 (anonymity); (m) Sexual Offences (Conspiracy and Incitement) Act 1996, ss 23,5(material); (n) Sexual Offences (Protected Material) Act 1997, s 8 (not yet in force); (o) Criminal Justice and Police Act 2001, ss 46-7 (adverts re prostitution); (p) Criminal Justice and Immigration Act 2008, ss 63-8 (images); (q) Coroners and Justice Act 2009, ss 62-8 (images)

${ }^{85}$ viz. Public Meetings Act 1908, Public Order Acts 1936 \& 1986, Representation of the People Act 1983, s 97, Crime and Disorder Act 1998 (dealing with religious and racial hatred), Crimes committed by Crown Employees (i.e. Criminal Jurisdiction Act 1802 and Criminal Justice Act 1948, s 31), Official Secrets Acts 1911 \& 1989, Incitement to Disaffection Act 1934 (seducing members of the armed forces).

${ }^{86}$ viz. Licensing Acts 1872 \& 1902, Policing and Crime Act 2009, s 30, Criminal Justice and Police Act 2001, s 12, Sporting Events (Control of Alcohol etc) Act 1985, Licensing Act 2003, ss 137-44, Violent Crime Reduction Act 2006, ss 1-14, 27.

${ }^{87}$ viz. Fireworks Act 2003, Explosives Act 1875, s 80, Highways Act 1980, s 161, Sporting Events (Control of Alcohol) Act 1985, ss 2A-4 and the Fireworks Act 1951

${ }^{88}$ viz. Criminal Justice and Public Order Act 1994, s 1994, s 167(1), Vehicle (Crime) Act 2001. The Aggravated Vehicle Taking Act 1992 amends the Theft Act 1968 (thus, it should be placed with financial crimes). The Criminal Attempts Act 1981, s 9 should be placed with Crimes against the Person. The Legal Aid, Sentencing and Punishment of Offenders Act 2012, s 143 (causing injury by dangerous driving) should be left in the Road Traffic Act 1988.

${ }_{89}^{8 i z}$. the Football (Offences) Act 1991, Football Spectators Act 1989 and the Criminal Justice and Public Order Act 1994, ss 166 \& 166A.

${ }^{90}$ viz. Misuse of Drugs Act 1971, Drug Trafficking Act 1994 and Drugs Act 2005. Material not concerning crimes should be put in an annex. ${ }^{91}$ viz. Prevention of Crime Act 1953, ss 1 \& 1A (offensive weapon), Restriction of Offensive Weapons Act 1959, s 1, Criminal Justice Act 1988, ss 139-42, Knives Act 1997, Crossbows Act 1987, Violent Crime Reduction Act 2006, ss 28-9 and the Criminal Justice and Public Order Act 1994, s 60.

92 viz. Firearms Acts 1968 \& 1982, Firearms Amendment Acts 1988 \& 1997and the Violent Crime Reduction Act 2006, ss 28-9, 32, 35-9.

${ }^{93}$ viz. OPA 1861, s 2830, 64-5, Explosives Act 1875 and the Explosives Substances Act 1883.

${ }^{94}$ viz. Terrorism Acts 2000 \& 2006, Prevention of Terrorism Act 2005, Criminal Law Act 1977, s 51 and the Anti-Terrorism, Crime and Security Act 2001.

${ }_{95}$ viz. (a) Offences against the Person Act 1861, ss 4,5, 9-10 (homicide), (b) Homicide Act 1957, ss 1, 2, 4 (homicide); (c) Suicide Act 1961, ss 1-2B (suicide); (d) Domestic Violence, Crime \& Victims Act 2004, ss 5-8 (death of vulnerable adult); (e) Corporate Manslaughter \& Homicide Act 2007, ss 1-24 (corporate homicide etc); (f) Coroners and Justice Act 2009, ss 54-5 (murder).

${ }^{96}$ viz. (a) Criminal Justice Act 1988, ss 134-5, 8 (torture); (b) Female Genital Mutilation Act 2003, ss 1-6 (genital mutilation).

${ }^{97}$ viz. (a) Slave Trade Acts 1824,1843 \& 1873; (b) Taking of Hostages Act 1982, ss 1,2 5 (hostages).

${ }^{98}$ viz.Offences against the Person Act 1861.

${ }_{99}$ viz. (a) Offences against the Person Act 1861, s 16 (threats to kill); (b) Administration of Justice Act 1970, s 40 (harassing debtors); (c) Malicious Communications Act 1988, s 1 (distressing letters); (d) Criminal Justice \& Public Order Act 1994, s 154 (intentional harassment); (e) Protection from Harassment Act 1997, s 1-13 (harassment); (f) Criminal Justice \& Police Act 2001,s 42, 42A (harassment in home).

${ }^{100}$ viz. (a) Offences against the Person Act 1861, ss 27, 58-60 (abortion etc); (b)Infant Life (Preservation) Act 1929, s 1-2 (child destruction); (c) Children and Young Persons Act 1933, ss 1,4,11-2 (various); (d) Infanticide Act 1938, s 1 (infanticide); (e) Children and Young Persons Act 1963, ss 37-40 (performances by children); (f) Abortion Act 1967, ss 1-6 (abortion); (g) Tattooing of Minors Act 1969, ss 1-3 (tattooing of minors); (h) Child Abduction Act 1984, ss 1-10 (child abduction); (i) Surrogacy Arrangements Act 1985, ss 1-4 (surrogacy); (j) Domestic Violence, Crime \& Victims Act 2004, s 5 (death of child).

${ }^{101}$ (a) Criminal Law Act 1977, ss 1-5 (conspiracy); (b) Criminal Law Act 1967, ss 4-5 (assisting, concealing); (c) Criminal Attempts Act 1981, ss 1-4, 6 (attempts); (d) Criminal Justice Act 1987, s 12 (conspiracy to defraud); (e) Serious Crime Act 2007, ss 44-6, 47-9(assisting). ${ }_{102}$ viz (a) Evidence Act 1851, s 15 (forgery); (b) Forgery Act 1861, ss 34,36-7(forged registers); (c) Documentary Evidence Act 1868, s 4 (forgery), (d) Debtors Act 1869, s 13 (fraud re obtaining credit); (e) Documentary Evidence Act 1882, ss 36-7 (forgery); (f) Criminal Justice Act 1925, s 3 (forgery); (g) Honours (Prevention of Abuses) Act 1925, s1 (fraud re grant of honours); (h) Forgery \& Counterfeiting Act 1981, ss 1-10, 14-22, 24-5, 27-8 (forgery); (i) Criminal Justice Act 1991, s 29A (false statements); (j) Criminal Justice Act 1993, ss 52-64 (insider dealing); (k) Fraud Act 2006, ss 1-13 (fraud); (1) Bribery Act 2010, ss 1-16 (bribery).

${ }_{103}$ viz. (a) Malicious Damage Act 1861, ss 35-6, 58 (criminal damage)(this should be repealed, see 3(c)); (b) Public Stores Act 1875, ss 1-8, 12-13 (public stores); (c) Theft Act 1968, ss 1-32 (theft); (d) Criminal Damage Act 1971, ss 1-7, 9 (criminal damage); (e) Unsolicited Goods \& Services Act 1971, ss 1-5 (unsolicited goods); (f) Criminal Law Act 1977, ss 6-10, 12, 12A (trespassers); (g) Theft Act 1978, ss3,4 (making off); (h) Computer Misuse Act 1990, ss 1-16 (computers); (i) Criminal Justice and Public Order Act 1994, ss 61-79 (trespassers etc); (j) Mobile Telephones (Re-programming) Act 2002, ss 1-2 (mobiles); (k) Legal Aid, Sentencing and Punishment etc Act 2012, s 144 (trespassers). 


\section{POSITION FROM 1890-1970 - OTHER LEGISLATION}

The position as to other legislation which contains crimes, post-1890, is also much simpler - not least, in that there is less legislation. Thus:

- Highwavs. There are few Acts in the period 1890-1970 and many are now piecemeal. ${ }^{104}$ These include the Road Traffic Act 1930 , Road and Rail Traffic Act 1933, Miscellaneous Financial Provisions Act 1955 (spent); Road Traffic Act 1960 and the Transport Acts 1962 and 1968. These should be consolidated. Minor crimes are contained in the Road Traffic Act 1960, s 232 ${ }^{105}$ as well as various sections of the Transport Act $1968 ;{ }^{106}$

- $\quad$ Railwavs \& Trams. There are few Acts in the period 1890-1970 and many are now piecemeal. ${ }^{107}$ These include the Railway Fires Act 1905 (obsolete), Railway Fires 1905 (Amendment) Act 1923 (obsolete); Mines (Working Facilities and Support) Act 1923, London Passenger Transport Act 1933, Road and Traffic Act 1933, Railway and Canal Commission (Abolition) Act 1949, Transport Act 1962 (dealing with the Railways Board). These should be consolidated with earlier legislation on railways. They appear to contain no minor crimes;

- Canals, Shipping, Ports \& Harbours. There are few Acts in the period 1890-1970. ${ }^{108}$ These include the Canals Protection (Londonl) Act 1898 and the Railway and Canal Commission (Abolition) Act 1949 (spent). In the case of ports and harbours, there are the Sea Fish Industry Act 1951, Transport Charges etc (Miscellaneous Provisions) Act 1954, Harbours Act 1964, Docks and Harbours Act 1966 and the Port of London Act 1968. The latter contains minor crimes, for example s 44 (false information and evasion of charges); ${ }^{109}$

- Hackney Carriages. There are few Acts in the period 1890-1970 and many are now piecemeal. ${ }^{110}$ These include the London Cab Act 1896 and the London Cab and Stage Carriage Act 1907. They should be consolidated with earlier legislation on hackney carriages.

In conclusion, the Law Commission should request the DfT to consolidate legislation on highways, railways, tramways and hackney carriages. And, Defra that on canals.

\section{CONCLUSION}

Presently, our criminal legislation is badly fragmented. It should be consolidated into 4 Crime Acts. However, for this to be achieved, the Law Commission needs to review all criminal legislation pre-1890 - as well as a few pieces of legislation post-1890 - which are obsolete (see Appendix B). It would also be useful for the Law Commission to review obsolete criminal procedure, pre-1890, and recommend its repeal or modernisation (see Appendix B). This will leave the MOJ (or Home Office) to consolidate remaining crimes into 4 Crime Acts in the following order (easiest first), which is:
(a) Sex crimes; ${ }^{111}$
(b) Public order crimes;
(c) Crimes against the person;
(d) Financial and property crimes.

As well as reviewing the obsolete legislation in Appendix B, the Law Commission should review - and recommend the abolition of obsolete common law crimes - see Appendix C. Remaining common law crimes can then be inserted into the 4 Crime Acts. Finally, it is asserted that the Law Commission should request the relevant Government departments to consolidate older legislation on:
(a) Railways and tramways (DfT);
(b) Canals (Defra);
(c) Harbours, ports \& dockyards;
(d) Markets and fairs;
(e) Hackney carriages (taxis) (DfT and TfL);
(f) Water (Defra);
(g) Companies.

\footnotetext{
${ }^{104}$ See Halsbury, Statutes, vol 36.

${ }^{105}$ It deals with the duty to give information as to a driver's identity in certain cases.

${ }^{106}$ See e.g. ss 97AA (forgery of seals etc on recording equipment), etc

${ }^{107}$ See generally Halsbury, Statutes, vol 36.

108 Ibid.

${ }^{109}$ See also ss 136, 199-204etc. See generally, Halsbury, Statutes, vol 39.

${ }^{110}$ See generally, Halsbury, Statutes, vol 36.

111 This is the easiest since it is a matter of consolidating some 20 pieces of legislation with the Sexual Offences Act 2003.
} 
Given that much of (c), (d) and (g) is likely obsolete, it would be a good idea for the Law Commission to advise that an expert be appointed to review its worth and whether much of it can now be repealed, as obsolete. 


\section{Appendix A: ACTS OF PARLIAMENT: 1267 - 1925}

Acts in italics - obsolete or a compelling case for review.

Date

$\underline{\text { Criminal }}^{112}$

Statute of Westminster $\left(1^{\text {st }}\right)$

Bearing of Armour

Law Presentment

Treason Act

Liberty of Subject

Justices of the Peace Act

None to Answer without Due Process

Treason Act

Treason Act

Treason Act

Habeas Corpus Act

Constables Protection Act

Habeas Corpus Act (Ireland) Act

Offences at Sea Act

Criminal Jurisdiction Act

Habeas Corpus Act

Habeas Corpus Act

Writ of Subpoena Act

Witnesses Act

Treason Act

Habeas Corpus Act

Vagrancy Act

Slave Trade Act

Juries Act

Universities Act

Criminal Law Act

Metropolitan Police Act

Statutory Declarations Act (repeal in part)

Highway Act

Piracy Act

Metropolitan Police Act

Metropolitan Police Courts Act

Treason Act

Slave Trade Act

Town Police Clauses Act

Treason Felony Act

Indictable Offences Act

Admiralty Offences (Colonial) Act

Piracy Act

Criminal Justice Administration Act

Criminal Procedure Act

Penal Servitude Act

Remission of Penalties Act

Metropolitan Police Act

Admiralty Offences (Colonial) Act

Accessories and Abettors Act

Malicious Damage Act

Forgery Act

Offences against the Person Act

Habeas Corpus Act

Metropolitan Police Act

Metropolitan Streets Act (street offences)

Metropolitan Streets Act Amendment Act

Criminal Law Amendment Act

Debtors Act (s 13, fraudulently obtaining credit)

Foreign Enlistment Act

Licensing Act

Slave Trade Act

Explosives Act

Public Stores Act

Territorial Waters Jurisdiction Act

Convention (Ireland) Repeal Act (unlawful assemblies)

Explosive Substances Act

Inebriates Act

Library Offences Act

Inebriates Act

${ }^{112}$ For the Game Acts etc see under heading 'Animals'. 


$\begin{array}{lll}1902 & \text { Licensing Act } & 5 \\ 1908 & \text { Public Meeting Act } & 2 \\ 1911 & \text { Perjury Act } & 16 \\ 1911 & \text { Official Secrets Act } & \\ 1919 & \text { Aliens Restriction (Amendment) Act 1919 (s3, see also Foreign and Colonial) } & 9 \\ 1920 & \text { Official Secrets Act } & 1\end{array}$

72 Acts

\section{$\underline{\text { Constitutional }}^{113}$}

\begin{tabular}{|c|c|}
\hline 1297 & Confirmation of the Charters \\
\hline 1297 & Statute concerning Tallage \\
\hline 1297 & Magna Carta (repeal some words) \\
\hline $1297 ?$ & Prerogativa Regis \\
\hline 1322 & Revocatio Novarum Ordinationum \\
\hline 1350 & Status of Children Born Abroad \\
\hline 1382 & Summons to Parliament \\
\hline 1405 & Liberties, Charters and Statutes Confirmed \\
\hline 1415 & Confirmation of Charters and Statutes \\
\hline 1423 & Confirmation of Liberties \\
\hline 1512 & Privilege of Parliament Act \\
\hline 1539 & House of Lords Precedence Act \\
\hline 1603 & Privilege of Parliament Act \\
\hline 1623 & Crown Lands Act \\
\hline 1627 & Petition of Right \\
\hline 1660 & Tenures Abolition Act \\
\hline 1661 & Free and Voluntary Present to HM \\
\hline 1688 & Convention Parliament \\
\hline 1688 & Royal Mines Act \\
\hline 1688 & Bill of Rights \\
\hline 1688 & Great Seal Act \\
\hline 1688 & Coronation Oath Act \\
\hline 1689 & Crown and Parliament Recognition Act \\
\hline 1693 & Royal Mines Act \\
\hline 1694 & Meeting of Parliament \\
\hline 1700 & Act of Settlement \\
\hline 1702 & Crown Lands Act \\
\hline 1702 & Demise of the Crown Act \\
\hline 1706 & Union with Scotland Act \\
\hline 1707 & Succession to the Crown Act \\
\hline 1707 & Union with Scotland (Amendment) Act \\
\hline 1711 & Princess Sophia's Precedence Act \\
\hline 1727 & Demise of the Crown Act \\
\hline 1737 & Parliamentary Privilege Act \\
\hline 1770 & Parliamentary Privilege Act \\
\hline 1793 & Acts of Parliament (Commencement) Act \\
\hline 1797 & Meeting of Parliament Act \\
\hline 1799 & Meeting of Parliament Act \\
\hline 1800 & Crown Private Estate Act (rep some words) \\
\hline 1800 & Union with Ireland Act \\
\hline 1801 & House of Commons (Disqualification) Act \\
\hline 1801 & Crown Debts Act \\
\hline 1808 & Acts of Parliament (Expiration) Act \\
\hline 1823 & Crown Lands Act \\
\hline 1824 & Clerk of the Parliaments Act \\
\hline 1829 & Roman Catholic Relief Act (see also Ecclesiastical) \\
\hline 1837 & Civil List Act \\
\hline 1840 & Parliamentary Papers Act \\
\hline 1851 & Crown Lands Act \\
\hline 1852 & Commissioner of Works Act \\
\hline 1853 & Privy Council Registrar Act \\
\hline 1855 & Deputy Speaker Act \\
\hline 1856 & House of Commons Offices Act \\
\hline 1858 & Parliamentary Witnesses Act \\
\hline 1858 & Durham County Palatine Act \\
\hline 1859 & Clerk of the Council Act \\
\hline 1862 & Crown Private Estates Act \\
\hline 1866 & Parliamentary Oaths Act \\
\hline 1867 & Representation of the People Act \\
\hline 1867 & Prorogation Act \\
\hline 1869 & Parliamentary Returns Act \\
\hline
\end{tabular}

${ }^{113}$ Left out are documents of major constitutional importance. viz: (a) Magna Carta 1297; (b) Bill of Rights 1688; (c) Act of Settlement 1700; (d) Union with Scotland Act 1706; (e) Union with Scotland (Amendment) Act 1707; (f) Union with Ireland Act 1800. 
$\begin{array}{llr}1870 & \text { Meeting of Parliament Act } & 2 \\ 1871 & \text { Parliamentary Witnesses Oaths Act } & 2 \\ 1873 & \text { Crown Private Estates Act } & 5 \\ 1874 & \text { Great Seal (Offices) Act } & 7 \\ 1877 & \text { Crown Office Act } & 6 \\ 1879 & \text { Public Offices Fees Act } & 6 \\ 1884 & \text { Great Seal Act } & 3 \\ 1890 & \text { Crown Office Act } & 1 \\ 1894 & \text { Crown Lands Act } & 1 \\ 1894 & \text { Commissioners of Works Act } & 4 \\ 1896 & \text { Short Titles Act } & 2 \\ 1901 & \text { Demise of the Crown Act } & 3 \\ 1902 & \text { Osborne Estate Act } & 2 \\ 1910 & \text { Accession Declaration Act } & 2 \\ 1911 & \text { Parliament Act } & 3 \\ 1917 & \text { Chequers Estate Act } & \\ 1918 & \text { Parliament (Qualification of Women) Act } & \end{array}$

79 Acts

\begin{tabular}{|c|c|c|}
\hline Temp Incert & Statute concerning Tenants by the Curtesy & 1 \\
\hline 1267 & Statute of Marlborough & 4 \\
\hline 1285 & Statute of Westminster $\left(2^{\text {nd }}\right)$ & 1 \\
\hline 1289 & Quia Emptores & 3 \\
\hline 1535 & Statute of Uses & 3 \\
\hline 1666 & Cestui Que Vie & 2 \\
\hline 1707 & Cestui que Vie Act & 5 \\
\hline 1709 & Landlord and Tenant Act (repeal most) & 5 \\
\hline 1730 & Landlord and Tenant Act & 3 \\
\hline 1737 & Distress for Rent Act & 14 \\
\hline 1773 & Inclosure Act & 28 \\
\hline 1832 & Prescription Act & 20 \\
\hline 1833 & Inclosure and Drainage (Rates) Act & 3 \\
\hline 1833 & Fines and Recoveries Act (repeal in part) & 43 \\
\hline 1833 & Dower Act (repeal in part) & 3 \\
\hline 1844 & Execution Act & 1 \\
\hline 1845 & Inclosure Act & 6 \\
\hline 1846 & Inclosure Act & 6 \\
\hline 1847 & Inclosure Act & 5 \\
\hline 1848 & Inclosure Act & 4 \\
\hline 1849 & Inclosure Act & 2 \\
\hline 1845 & Lands Clauses Consolidation Act & 93 \\
\hline 1852 & Inclosure Act & 8 \\
\hline 1852 & Common Law Procedure Act & 7 \\
\hline 1854 & Literary and Scientific Institutions Act & 30 \\
\hline 1854 & Inclosure Act & 17 \\
\hline 1857 & Inclosure Act & 7 \\
\hline 1859 & Inclosure Act & 7 \\
\hline 1860 & Lands Clauses Consolidation Acts Amendment Act & 5 \\
\hline 1864 & Improvement of Land Act & 66 \\
\hline 1866 & Metropolitan Commons Act & 30 \\
\hline 1867 & Sale of Land by Auction Act & 8 \\
\hline 1868 & Inclosure etc and Expenses Act & 1 \\
\hline 1869 & Metropolitan Commons Amendment Act & 2 \\
\hline 1870 & Apportionment Act & 7 \\
\hline 1870 & Limited Owners Residence Act & 8 \\
\hline 1871 & Limited Owners Residences (1870) Amendment Act & 3 \\
\hline 1876 & Commons Act & 17 \\
\hline 1878 & Metropolitan Commons Act & 2 \\
\hline 1878 & Commons (Expenses) Act & 3 \\
\hline 1879 & Commons Act & 2 \\
\hline 1879 & Customs Buildings Act & 5 \\
\hline 1881 & Conveyancing Act & 1 \\
\hline 1881 & Inland Revenue Buildings Act & 5 \\
\hline 1882 & Commonable Rights Compensation Act & 5 \\
\hline 1882 & Settled Land Act & 1 \\
\hline 1892 & Military Lands Act & 21 \\
\hline 1895 & Law of Distress Amendment Act & 4 \\
\hline 1897 & District Councils (Water Supply Facilities) Act (land charged for water supply) & 6 \\
\hline 1897 & Military Lands Act & \\
\hline 1897 & Land Transfer Act & \\
\hline 1899 & Improvement of Land Act & \\
\hline 1899 & Commons Act & \\
\hline
\end{tabular}




$\begin{array}{lll}1899 & \text { Bodies Corporate (Joint Tenancy) Act } & 2 \\ 1900 & \text { Military Lands Act } & 5 \\ 1903 & \text { Military Lands Act } & 2 \\ 1906 & \text { Open Spaces Act } & 24 \\ 1906 & \text { Crown Lands Act } & 5 \\ 1908 & \text { Small Holdings and Allotment Act } & 28 \\ 1908 & \text { Commons Act } & 3 \\ 1919 & \text { Land Settlement (Facilities) Act } & 15 \\ 1920 & \text { Defence of the Realm Act (Acquisition of Land) } \\ 1922 & \text { Law of Property Act } & 6 \\ 1922 & \text { Allotments Act } & 8 \\ 1924 & \text { Law of Property (Amendment) Act } & 15\end{array}$

\section{Acts}

(a) General

\begin{tabular}{|c|c|c|}
\hline 1533 & Submission of the Clergy Act & 2 \\
\hline 1533 & Appointment of Bishops Act & 3 \\
\hline 1533 & Ecclesiastical Licences Act & 14 \\
\hline 1534 & Suffragan Bishops Act & 6 \\
\hline 1536 & Tithe Act & $\overline{5}$ \\
\hline 1547 & Sacrament Act & $\overline{1}$ \\
\hline 1548 & Tithes and Offerings & 1 \\
\hline 1558 & Act of Supremacy & 1 \\
\hline 1588 & Simony Act & 8 \\
\hline 1662 & Act of Uniformity & 2 \\
\hline 1688 & Simony Act & 1 \\
\hline 1708 & Parochial Libraries Act & 11 \\
\hline 1714 & Queen Anne's Bounty Act & $\underline{4}$ \\
\hline 1776 & Clergy Residences Repair Act & $\overline{2}$ \\
\hline 1804 & Clergy Ordination Act & 1 \\
\hline 1811 & Gifts for Churches Act & 2 \\
\hline 1816 & Burial Ground Act & 4 \\
\hline 1822 & Church Building Act & $\underline{2}$ \\
\hline 1825 & Marriages Confirmation Act & 2 \\
\hline 1829 & Roman Catholic Relief Act (see also under Constitutional) & \\
\hline 1830 & Marriage Confirmation Act & 1 \\
\hline 1832 & Ecclesiastical Corporations Act & $\underline{6}$ \\
\hline 1832 & Tithe Act & $\overline{7}$ \\
\hline 1836 & Ecclesiastical Leases Act & 9 \\
\hline 1836 & Ecclesiastical Leases (Amendment) Act & $\underline{1}$ \\
\hline 1836 & Tithe Act & $\overline{2}$ \\
\hline 1836 & Ecclesiastical Commissioners Act & 10 \\
\hline 1837 & Parish Notices Act & 2 \\
\hline 1838 & Queen Anne's Bounty Act & 2 \\
\hline 1838 & Parsonages Act & 2 \\
\hline 1838 & Pluralities Act & 58 \\
\hline 1839 & Tithe Act & 2 \\
\hline 1840 & Ecclesiastical Commissioners Act & 21 \\
\hline 1841 & Ecclesiastical Commissioners Act & 7 \\
\hline 1841 & Bishops in Foreign Countries Act & 4 \\
\hline 1842 & Ecclesiastical Houses of Residence Act & 9 \\
\hline 1842 & Ecclesiastical Leasing Act & 28 \\
\hline 1843 & New Parishes Act & 1 \\
\hline 1844 & Lecturers and Parish Clerks Act & 4 \\
\hline 1849 & Sequestration Act & 2 \\
\hline 1850 & Ecclesiastical Commissioners Act & 5 \\
\hline 1853 & Colonial Bishops Act & 1 \\
\hline 1855 & Places of Worship Registration Act & $\overline{13}$ \\
\hline 1858 & Jews Relief Act & 1 \\
\hline 1858 & Ecclesiastical Leasing Act & 11 \\
\hline 1858 & Bishops Trusts Substitution Act & 5 \\
\hline 1860 & Ecclesiastical Courts Jurisdiction Act & 4 \\
\hline 1860 & Tithe Act & 1 \\
\hline 1860 & Ecclesiastical Commissioners Act & 3 \\
\hline 1865 & Ecclesiastical Leases Act & \\
\hline 1865 & Parsonages Act & \\
\hline 1865 & Clerical Subscription Act & \\
\hline 1866 & Ecclesiastical Commissioners Act & \\
\hline 1868 & Compulsory Church Rate Abolition Act & \\
\hline 1868 & Army Chaplains Act & \\
\hline 1869 & Residence of Incumbents Act & \\
\hline 1869 & New Parishes Acts and Church Building Acts Amendment Act & \\
\hline 1870 & Clerical Disabilities Act & \\
\hline
\end{tabular}

\section{Ecclesiastical}




$\begin{array}{ll}1871 & \text { Ecclesiastical Titles Act } \\ 1871 & \text { Prayer Book (Tables of Lessons) Act } \\ \mathbf{1 8 7 1} & \text { Sequestration Act } \\ \mathbf{1 8 7 2} & \text { Baptismal Fees Abolition Act } \\ 1872 & \text { Church Seats Act } \\ 1873 & \text { Places of Worship Sites Act } \\ 1874 & \text { Colonial Clergy Act } \\ 1874 & \text { Births and Deaths Registration Act } \\ 1882 & \text { Places of Worship Sites Amendment Act } \\ \mathbf{1 8 8 5} & \text { Pluralities Acts Amendment Act } \\ 1888 & \text { Suffragans Nomination Act } \\ 1897 & \text { Isle of Man (Church Building and New Parishes) Act } \\ 1898 & \text { Benefices Act } \\ 1898 & \text { Suffragan Bishops Act } \\ 1914 & \text { Welsh Church Act } \\ 1919 & \text { Welsh Church (Temporalities) Act } \\ 1919 & \text { Church of England Assembly (Powers) Act } \\ 1920 & \text { Places of Worship (Enfranchisement) Act } \\ 1920 & \text { Convocations of the Clergy Measure } \\ 1921 & \text { Tithe Annuities Apportionment Act } \\ 1922 & \text { Revised Tables of Lessons Measure } \\ 1923 & \text { Ecclesiastical Dilapidations Act } \\ & \end{array}$

\section{(b) Burial \& Cremation}

$\begin{array}{ll}1847 & \text { Cemeteries Clauses Act } \\ 1852 & \text { Burial Act } \\ 1853 & \text { Burial Act } \\ 1855 & \text { Burial Act } \\ 1857 & \text { Burial Act } \\ 1859 & \text { Burial Act } \\ 1864 & \text { Registration of Burials Act } \\ 1867 & \text { Consecration of Churchyards Act } \\ \mathbf{1 8 6 8} & \text { Consecration of Churchyards Act } \\ 1880 & \text { Burial Laws Amendment Act } \\ 1884 & \text { Disused Burial Grounds Act } \\ 1885 & \text { Metropolitan Board of Works (Various Powers) Act (burial grounds) } \\ 1902 & \text { Cremation Act }\end{array}$

\section{Acts}

Acts underlined the Church of England intend to repeal. Sections not provided for in the case of those post 1860 since the C of E also intend to repeal a number of them.

\section{$\underline{\text { Transport }}$}

\section{(a) Carriage (inc Hackney Carriage)}

$\begin{array}{lll}1830 & \text { Carriers Act } & 9 \\ 1831 & \text { London Hackney Carriage Act } & 9 \\ 1843 & \text { London Hackney Carriages Act } & 18 \\ 1850 & \text { London Hackney Carriages Act } & 2 \\ 1853 & \text { London Hackney Carriage Act } & 8 \\ 1869 & \text { Metropolitan Public Carriage Act } & 13 \\ 1889 & \text { Town Police Clauses Act (spent, applies to horse drawn buses) } \\ 1896 & \text { London Cab Act } & 6 \\ 1907 & \text { London Cab and Stage Carriage Act } & 2\end{array}$

\section{(b) Railways \& Trams}

$\begin{array}{lll}1839 & \text { Highway (Railway Crossings) Act } & 1 \\ 1842 & \text { Railway Regulation Act } & 4 \\ 1845 & \text { Railways Clauses Consolidation Act } & 103 \\ 1861 & \text { Locomotive Act (spent) } & 1 \\ 1863 & \text { Railways Clauses Act } & 19 \\ 1867 & \text { Railway Companies Act } & 5 \\ 1868 & \text { Regulation of Railways Act } & 9 \\ 1870 & \text { Tramways Act } & 42 \\ 1873 & \text { Regulation of Railways Act } & 3 \\ 1888 & \text { Railway and Canal Traffic Act } & 10 \\ 1889 & \text { Regulation of Railways Act (spent) } & 3 \\ 1905 & \text { Railway Fires Act } & 4 \\ 1923 & \text { Railway Fires Act (1905) Amendment Act } & 1 \\ 1923 & \text { Mine Working and Facilities Act } & 19\end{array}$


(c) $\underline{\text { Canals }}$

$\begin{array}{llc}1845 & \text { Canal Carriers Act } & 11 \\ 1847 & \text { Canal (Carriers) Act } & 3 \\ 1898 & \text { Canals Protection (London) Act } & 8\end{array}$

(d) Shipping \& Ferries

1853

1854

1919

(e) Others

1919

Ministry of Transport Act

Merchant Shipping Law Amendment Act

Merchant Shipping Repeal Act

Ferries (Acquisition by Local Authorities) Act

1

5

\section{$\underline{\text { Schools \& Universities }}$}

\section{(a) Oxbridge \& Durham}

1571

1854

1856

1857

1860

1862

1865

1871

1877

1923

\section{(b) Schools etc}

$\begin{array}{ll}1841 & \text { School Sites Act } \\ 1844 & \text { School Sites Act } \\ 1849 & \text { School Sites Act } \\ 1851 & \text { School Sites Act } \\ 1852 & \text { School Sites Act } \\ 1855 & \text { School Grants Act } \\ 1868 & \text { Public Schools Act } \\ 1871 & \text { College Charter Act } \\ 1891 & \text { Army Schools Act } \\ 1892 & \text { Technical and Industrial Institutions Act } \\ 1898 & \text { Elementary School Teachers (Superannuation) Act } \\ 1900 & \text { Elementary Schoolteachers Superannuation (Jersey) Act } \\ 1912 & \text { Elementary School Teachers (Superannuation) Act } \\ 1918 & \text { Education Act }\end{array}$

Oxford and Cambridge Act

Oxford University Act 26

Cambridge University Act 26

Oxford University Act

Oxford University Act 1

Oxford University Act

Oxford University; Vinerian Foundation Act 3

Universities Tests Act

Universities of Oxford and Cambridge Act 5

Universities of Oxford and Cambridge Act

24 Acts

\section{$\underline{\text { Treasury }}$}

Bank of England Act

National Debt Reduction Act (amend)

Stamp Act

Consolidated Fund Act

National Debt Commissioners Act (amend)

National Debt Reduction Act

Bank Charter Act

Paymaster General Act

Treasury Instruments (Signature) Act

Bank Notes Act

Stamp Act

Public Revenue and Consolidated Charges Fund Act

Exchequer and Audit Departments Act

National Debt Reduction Act

Exchequer Extra Receipts Act

National Debt Act

Customs Consolidation Act

Treasury Bills Act

Revenue, Friendly Societies and National Debt Act

Revenue Act

National Debt (Conversion of Stock) Act

National Debt (Conversion) Act

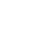

8

.




$\begin{array}{lll}1889 & \text { Revenue Act } & 3 \\ 1889 & \text { National Debt Act } & 3 \\ 1891 & \text { Stamp Act } & 33 \\ 1891 & \text { Stamp Duties Management Act } & 14 \\ 1892 & \text { Bank Act } & 2 \\ 1892 & \text { National Debt (Stockholders Relief) Act } & 5 \\ 1895 & \text { Finance Act } & 1 \\ 1897 & \text { Foreign Prison-Made Goods Act } & 3 \\ 1898 & \text { Revenue Act } & 4 \\ 1898 & \text { Finance Act } & 2 \\ 1899 & \text { Finance Act } & 3 \\ 1900 & \text { Finance Act } & 2 \\ 1901 & \text { Finance Act } & 2 \\ 1903 & \text { Revenue Act } & 2 \\ 1907 & \text { Finance Act } & 2 \\ 1909 & \text { Revenue Act } & 2 \\ 1915 & \text { Finance (No 2) Act } & 2 \\ 1916 & \text { Finance Act } & 2 \\ 1917 & \text { Finance Act } & 2 \\ 1921 & \text { Finance Act } & 3 \\ 1921 & \text { Exchequer and Audit Departments Act } & \end{array}$

43 Acts

\section{Courts \& Evidence}

\section{(a) Courts \& Trials}

$\begin{array}{ll}1828 & \text { Revenue Solicitors 'Act } \\ 1833 & \text { Judicial Committee Act (privy council) } \\ 1836 & \text { Stannaries Act (old mining courts) } \\ 1843 & \text { Judicial Committee Act (privy council) } \\ 1844 & \text { Judicial Committee Act (privy council) } \\ 1855 & \text { Stannaries Act (old mining courts) } \\ 1874 & \text { Courts (Colonial) Jurisdiction Act } \\ 1883 & \text { Trials of Lunatics Act } \\ 1890 & \text { Colonial Courts of Admiralty Act } \\ 1895 & \text { Judicial Committee Amendment Act (privy council) } \\ 1896 & \text { Stannaries Court (Abolition) Act (old mining courts) } \\ 1908 & \text { Appellate Jurisdiction Act (privy council) } \\ 1915 & \text { Judicial Committee Act (privy council) }\end{array}$

(b) Police \& Police Receiver

$\begin{array}{ll}1861 & \text { Metropolitan Police (Receiver) Act } \\ 1867 & \text { Metropolitan Police (Receiver) Act } \\ 1886 & \text { Metropolitan Police Act } \\ 1887 & \text { Metropolitan Police Act } \\ 1895 & \text { Metropolitan Police (Receiver) Act } \\ 1897 & \text { Metropolitan Police Courts Act } \\ 1897 & \text { Police (Property) Act } \\ 1899 & \text { Metropolitan Police Act } \\ 1916 & \text { Police, Factories etc (Miscellaneous Provisions) Act } \\ 1923 & \text { Special Constables Act }\end{array}$

\section{(c) Evidence}

$\begin{array}{ll}1845 & \text { Evidence Act } \\ 1851 & \text { Evidence Act } \\ 1853 & \text { Evidence Amendment Act } \\ 1854 & \text { Attendance of Witnesses Act } \\ 1859 & \text { Colonial Affidavits Act } \\ 1871 & \text { Prevention of Crimes Act } \\ 1872 & \text { Review of Justice Decisions Act } \\ 1865 & \text { Criminal Procedure Act } \\ 1868 & \text { Documentary Evidence Act } \\ 1882 & \text { Documentary Evidence Act } \\ 1892 & \text { Witnesses (Public Inquiries) Protection Act } \\ 1895 & \text { Documentary Evidence Act } \\ 1898 & \text { Criminal Evidence Act }\end{array}$

Evidence Amendment Act

Review of Justice Decisions Act

Criminal Procedure Act

Witnesses (Public Inquiries) Protection Act

Criminal Evidence Act

\section{(d) Imprisonment}




\section{(e) Oaths \& Declarations}

$\begin{array}{lll}1775 & \text { Oaths Act } & 1 \\ 1835 & \text { Statutory Declarations Act } & 17 \\ 1868 & \text { Promissory Oaths Act } & 16 \\ 1871 & \text { Promissory Oaths Act } & 3 \\ 1889 & \text { Commissioners for Oaths Act } & 7 \\ 1891 & \text { Commissioners for Oaths Act } & 2\end{array}$

\section{(f) Legal Positions \& Fees}

$\begin{array}{lll}1801 & \text { Public Notaries Act } & 2 \\ 1843 & \text { Public Notaries Act } & 5 \\ 1872 & \text { Judges Salaries Act } & 2 \\ 1872 & \text { Law Officers Fees Act } & 3 \\ 1876 & \text { Treasury Solicitor Act } & 7 \\ 1887 & \text { Sheriffs Act } & 24 \\ 1896 & \text { Judicial Trustees Act } & 5\end{array}$

\section{(g) Cinque Ports}

$1821 \quad$ Cinque Ports Act 8

1855 Cinque Ports Act

\section{(h) Indictments \& Judgments}

$\begin{array}{lll}1838 & \text { Judgments Act } & 3 \\ 1915 & \text { Indictments Act } & 8 \\ 1920 & \text { Administration of Justice Act } & 8\end{array}$

(i) $\underline{\text { Other }}$

$\begin{array}{ll}1840 & \text { Non-Parochial Registers Act } \\ 1842 & \text { Limitation of Actions and Costs Act } \\ 1870 & \text { Forfeiture Act } \\ 1881 & \text { Summary Jurisdiction (Process) Act } \\ 1886 & \text { Riot (Damages) Act } \\ 1914 & \text { Criminal Justice Administration Act }\end{array}$

63 Acts

\section{Local Government}

\section{(a) Harbours \& Dockyards}

$\begin{array}{lll}1847 & \text { Harbours, Docks and Piers Clauses Act } & 92 \\ 1861 & \text { Harbours and Passing Tolls etc Act } & 12 \\ 1862 & \text { Harbours Transfer Act } & 11 \\ 1865 & \text { Dockyard Ports Regulation Act } & 21\end{array}$

(b) Water

$\begin{array}{lll}1847 & \text { Waterworks Clauses Act } & 93 \\ 1852 & \text { Metropolis Water Act } & 20 \\ 1863 & \text { Waterworks Clauses Act } & 20 \\ 1871 & \text { Metropolis Water Act } & 29 \\ 1879 & \text { Metropolis Management (Thames River Prevention of Floods) Amendment Act } & 27 \\ 1885 & \text { Water Rate Definition Act } & 3 \\ 1897 & \text { Metropolis Water Act } & 3 \\ 1897 & \text { District Councils (Water Supply Facilities) Act } & 6 \\ 1902 & \text { Metropolis Water Act } & 38 \\ 1907 & \text { Metropolitan Water Board (Charges) Act } & 23 \\ 1921 & \text { Metropolitan Water Board (Charges) Act } & 9\end{array}$

\section{(c) Markets \& Fairs}

$\begin{array}{ll}1847 & \text { Markets and Fairs Clauses Act } \\ 1868 & \text { Metropolitan Fairs Act } \\ 1871 & \text { Fairs Act } \\ 1873 & \text { Fairs Act } \\ 1887 & \text { Markets and Fairs (Weighing of Cattle) Act }\end{array}$

\section{(d) Parks \& Gardens}


1863

1872

(e) Public Health

1875

1890

1907

\section{(f) Public Works}

1854

1863

1874

1875

1876

1911

\section{(g) $\underline{\text { Rates }}$}

1872

1875

1919

\section{(h) Powers}

1882

1890

1892

1894

1900

1903

1907

1920

1921

1923

(i) Other

1847

1847

1882

1883

1888

1894

1894

1907

1916

54 Acts

\section{(a) Insurance}

1774

1774

1808

1865

1865

1867

1896

1906

1909

1923

\section{(b) Bills of Sale}

1878

1882

1890

1891

Town Gardens Protection Act

Parks Regulation Act

Public Health Act

Public Health Acts Amendment Act

Public Health Acts Amendment Act

32

10

16

Public Statutes (Metropolis) Act

Public Works and Fisheries Acts Amendment Act

Works and Public Buildings Act $\quad 5$

Public Works Loan Act $\quad 40$

Public Works Loans (Money) Act 2

$\begin{array}{lr}\text { Public Works Loans Act } & 2\end{array}$

Poor Rates Recovery Act

Jurisdiction in Rating Act

Statement of Rates Act

2
4

Metropolitan Board of Works (Various Powers) Act

London Council (General Powers) Act

London County Council (General Powers) Act

London County Council (General Powers) Act

London County Council (General) Powers Act

London County Council (General Powers) Act

London County Council (General Powers) Act

London County Council (General Powers) Act

London County Council (General Powers) Act

War Memorials (Local Authorities' Powers) Act

0

(1)




\section{(c) $\underline{\text { Pedlars }}$}

$1871 \quad$ Pedlars Act $\quad$ Pedlars Act 19

$1881 \quad$ Pedlars Act 2

(d) Negotiable Instruments \& Bills of Exchange

$1854 \quad$ Common Law Procedure Act 3

$1882 \quad$ Bills of Exchange Act 107

1917 Bills of Exchange (Time of Noting) Act 1

(e) Debtors \& Bankruptcy

$\begin{array}{ll}1869 & \text { Debtors Act } \\ 1878 & \text { Debtors Act } \\ 1914 & \text { Deeds of Arrangement Act }\end{array}$

Deeds of Arrangement Act

(f) $\underline{\text { Banks }}$

(g) Partnerships

1890

1907

(h) Others

1623

1677

1828

1845

1856

1878

1889

33 Acts

1845

1863

1869

1888

189

1892

1915

7 Acts

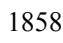

1860

2 Acts

1662

1820

1842

1855

1859

1860

1862

1864

1864

1864

1865

1865

1865

1865

1865

1869

1872
Partnership Act

Limited Partnerships Act

Statute of Monopolies

Statute of Frauds (guarantee)

Statute of Frauds Amendment Act (representations of character)

Auctioneers Act

Mercantile Law Amendment Act (guarantee, consideration)

Innkeepers Act (disposal of goods)

Factors Act

(1)

$$
\text { Factors Act }
$$

\section{Company}

Companies Clauses Consolidation Act

Companies Clauses Act

Companies Clauses Act

Companies Clauses Consolidation Act

Forged Transfers Act

Forged Transfers Act

Statutory Companies (Redeemable Stock) Act

\section{$\underline{\text { Medicine }}$}

Medical Act

Medical Act

\section{$\underline{\text { Ministry of Defence }}$}

City of London Militia Act

Militia (City of London) Act

Defence Act

Defence Act

Ordnance Board Transfer Act

Defence Act

Defence Act

Officers Commissions Act

Naval Agency and Distribution Act

Naval Prize Act

Defence Act Amendment Act

Defence Act

Navy and Marines (Wills) Act

Naval and Marine Pay and Pension Act

Greenwich Hospital Act

Navy and Marines (Property of Deceased) Act

Greenwich Hospital Act

Greenwich Hospital Act 


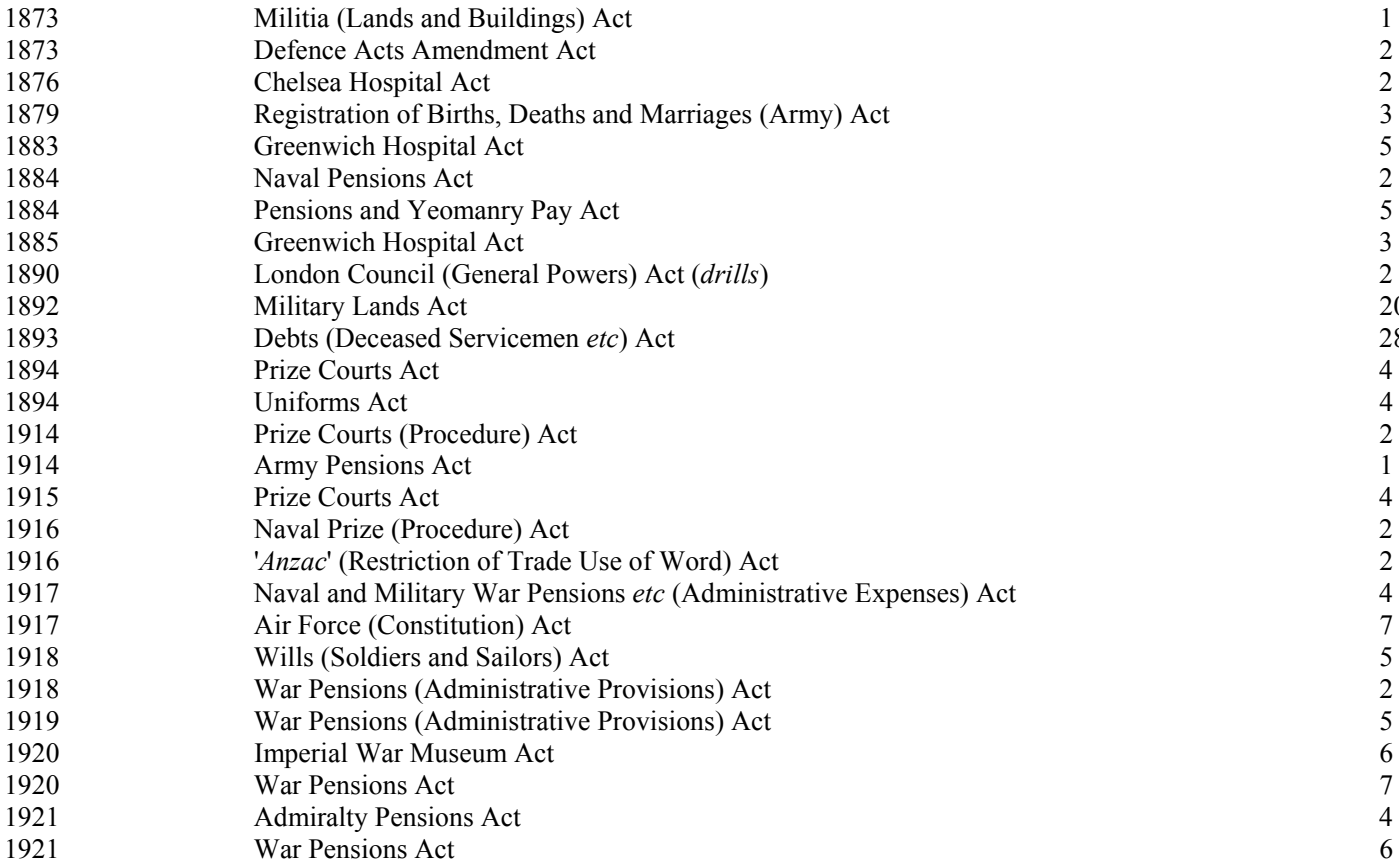

45 Acts

\section{$\underline{\text { Animals }}$}

Night Poaching Act

Game Act

Night Poaching Act

Poaching Prevention Act

Dogs Act

Ground Game Act

Hares Preservation Act

Ground Game (Amendment) Act

Dogs Act

Protection of Animals Act

10 Acts

\section{$\underline{\text { Agriculture \& Fisheries }}$}

1883

1889

1891

1891

1903

1919

1921

1923

8 Acts

\section{Acts}

Sea Fisheries Act

Board of Agriculture Act

Fisheries Act

Markets and Fairs (Weighing of Cattle) Act

Board of Agriculture and Fisheries Act

Ministry of Agriculture and Fisheries Act

Corn Sales Act

Agricultural Credits Act

\section{Colonial \& Foreign}

British Law Ascertainment Act

Colonial Laws Validity Act

Colonial Marriages Act

British Settlements Act

Foreign Jurisdiction Act

Colonial Boundaries Act

Evidence (Colonial Statutes) Act

Foreign Jurisdiction Act

Alderney (Transfer of Property etc) Act

Status of Aliens Act

Aliens Restriction (Amendment) Act (see also Criminal)

\section{Marriage \& Family}

Provisional Order (Marriages) Act

Marriage with Foreigners Act

Married Women's Property Act 
8 Acts

1920

\section{Act}

3 Acts

Married Women's Property Act

Marriage of British Subjects (Facilities) Act

Marriage of British Subjects (Facilities) Amendment Act

Maintenance Orders (Facilities for Enforcement) Act

Marriages Validity (Provisional Orders) Act

\section{$\underline{\text { Mining }}$}

Mining Industry Act

\section{Patents \& Trademarks}

Patents and Designs Act

Anglo-Portuguese Commercial Treaty Act

Anglo-Portuguese Commercial Treaty Act

\section{Pensions}

Pensions Commutation Act

\section{$\underline{\text { Telecoms }}$}

Telegraph Act

Newspapers, Printers and Reading Rooms Repeal Act Telegraph Act

Newspaper Libel and Registration Act

Submarine Telegraph Act

Libel Act

Libel Act

Law of Libel Amendment Act

Libel

\section{Wills \& Inheritance}

Inheritance Act

Wills Act

Law of Property Amendment Act(descent)

Confirmation and Probate Amendment Act Intestates Estates Act

Intestates' Estates Act

Colonial Probates Act

Married Women's Property Act (wills)

\section{Other}

Poynings' Law

Letters Patent Act

Sea-Sand (Devon \& Cornwall) Act

Calendar (New Style) Act

Calendar Act

Plate Assay (Sheffield and Birmingham) Act

Yelverton's Act (Ireland)

Weights and Measures Act

Nautical Almanack Act

Sunday Observance Act

St Helena Act

Ordnance Survey Act

Geological Survey Act

Queen's Remembrancer Act

Refreshment Houses Act

Domicile Act

Gun Barrel Proof Act

Board of Trade Arbitrations etc Act

Naval Knights of Windsor (Dissolution) Act

Statute Law Revision Act

Short Titles Act 


$\begin{array}{lll}1896 & \text { Judicial Trustees Act } & 5 \\ 1906 & \text { Public Trustee Act } & 15 \\ 1907 & \text { National Trust Act } & 26 \\ 1917 & \text { Titles Deprivation Act } & 4 \\ 1919 & \text { National Trust Charity Scheme Confirmation Act } & 2 \\ 1920 & \text { Census Act } & 9 \\ 1920 & \text { Employment of Women, Young Persons and Children Act } & 16 \\ 1922 & \text { Irish Free State (Consequential Provisions) Act } & 3\end{array}$

29 Acts

Summary: All Acts 1267-1925

$\begin{array}{lll}\text { Criminal } & \text { - Total } & 73 \\ \text { Constitutional } & \text { - Total } & 79 \\ \text { Land } & \text { - Total } & 65 \\ \text { Ecclesiastical } & \text { - Total } & 93 \\ \text { Transport } & \text { - Total } & 30 \\ \text { Schools } \text { etc } & \text { - Total } & 24 \\ \text { Treasury } & \text { - Total } & 43 \\ \text { Courts/Evidence } & \text { - Total } & 63 \\ \text { Local Government } & \text { - Total } & 54 \\ \text { Commercial \& Insurance } & \text { - Total } & 33 \\ & & \\ \text { Company } & \text { - Total } & 7 \\ \text { Medicine } & \text { - Total } & 2 \\ \text { Ministry of Defence } & \text { - Total } & 45 \\ \text { Animals } & \text { - Total } & 10 \\ \text { Agriculture \& Fisheries } & \text { - Total } & 8 \\ \text { Colonial \& Foreign } & \text { - Total } & 11 \\ \text { Pensions } & \text { - Total } & 2 \\ \text { Telecoms } & \text { - Total } & 5 \\ \text { Libel } & \text { - Total } & 3 \\ \text { Wills \& Inheritance } & - \text { Total } & 8 \\ \text { Marriage \& Family } & - \text { Total } & 8 \\ \text { Mining } & \text { - Total } & 1 \\ \text { Patents } & - \text { Total } & 3 \\ \text { Other } & - \text { Total } & 29\end{array}$

These Acts could be condensed to 15 or so. 


\section{Appendix B: OBSOLETE CRIMINAL \& CRIMINAL PROCEDURE LEGISLATION}

The Law Commission should review the following legislation on crimes and criminal procedure with a view to its repeal or where still of worth - its being placed in modern form in more recent legislation. However, in 3 cases, it would seem best for a legal expert to review legislation separately, given that it is convoluted, viz.

- $\quad$ Treason Acts. The Treason Act 1351 (other than treasons concerning a Queens Bench judge and violation of the sovereign's wife which have no caselaw and are obsolete). Also, the Treason Acts 1495, 1695, 1702 and 1814; ${ }^{114}$

- Habeas Corpus Acts. Acts of 1679, 1781, 1803, 1804, 1816 and 1862;

- $\quad$ Animals Acts. The Night Poaching Act 1828, Game Act 1831, Night Poaching Act 1844, Poaching Prevention Act 1862, Dogs Act 1871, Ground Game Act 1880, Hares Preservation Act 1892, Ground Game (Amendment) Act 1906, Dogs Act 1906 and Protection of Animals Act 1911, as well as later legislation.

Statute of Westminster $\left(1^{\text {st }}\right)$

Bearing of Armour

Law Presentment

Treason Act

Liberty of Subject

Justices of the Peace Act

None to Answer without Due Process

Treason Act

Simony Act

Simony Act

Treason Act

Treason Act

Constables Protection Act

Offences at Sea Act

Criminal Jurisdiction Act
No cases. Superceded by Representation of the People Act 1983, s 115 and firearms legislation. Repeal Act. ${ }^{115}$

No cases. Likely a temporary Act. Superceded by Treason Felony Act 1848 \& Public Order Act 1936 . Repeal Act. ${ }^{116}$

No cases. Repeats Magna Carta, ch 29. Remainder re privy council is obsolete. Repeal Act. ${ }^{17}$

2 crimes therein have no cases (killing QB judge/ violating sovereign's wife). See also above. Repeal wording.

No cases. Repeats Magna Carta, ch 29. Covered by Human Rights Act 1998. Repeal Act. ${ }^{118}$

Superceded by Justices of the Peace Act 1968 s 1(7) re binding over as well as other legislation. Repeal Act. ${ }^{119}$

No cases. Repeats Magna Carta, ch 29. Covered by Human Rights Act 1998. Repeal Act. ${ }^{120}$

\section{No cases. See above.}

Superceded by Bribery Act 2010. Repeal Act. ${ }^{121}$

Superceded by Bribery Act 2010. Repeal Act. ${ }^{122}$

No cases. Procedural. See above.

No cases. Likely expired in 1714 . See above.

Needs to be amended to equal JP's liability. Repeal Act. ${ }^{123}$

One sentence remains. Some wording obsolete. Modernise and insert in modern legislation. Repeal wording. ${ }^{124}$

Superceded by Criminal Justice Act 1848 and Criminal Law Act 1971. Repeal Act. ${ }^{125}$

\footnotetext{
${ }^{114}$ The law is analysed in the following articles by GS McBain on: (a) Abolishing the Crime of Treason(2007) 81 ALJ 94-134; (b) High Treason: Killing the Sovereign or Her Judges (2009) 20 KLJ 457-88; (c) High Treason: Violating the Sovereign's Wife (2009) Legal Studies,vol 29(2) 264-80; (d) Abolishing the Crime of Treason Felony (2007) 81 ALJ 812-38; (e) Modernising English Criminal Law (2010) Coventry LJ, vol 15, no 2 (deals with the Treason Act 1702).

${ }^{115}$ See GS McBain, Modernising English Criminal Law (2010) Coventry LJ, vol 15, no 2.

${ }^{116}$ Ibid, Abolishing Obsolete Legislation on Crimes \& Criminal Procedure (2010) Legal Studies, vol 30. No 3.

117 Ibid.

${ }^{118}$ Ibid.

${ }^{119}$ GS McBain, Modernising English Criminal Law (2010) Coventry LJ, vol 15, no 2.

${ }^{120}$ Ibid, Abolishing Obsolete Legislation on Crimes \& Criminal Procedure (2010) Legal Studies, vol 30 . No 3.

${ }^{121}$ Ibid, Abolishing Obsolete Legislation on Bribery (2011) Coventry LJ, vol 16, no 2.

122 Ibid.

${ }^{123}$ Ibid, Our Criminal Law should only be 200 Years out of Date (2014) Review of European Studies, vol 6, no 2

${ }^{124}$ It states 'All and every offence and offences which after the passing of this Act shall be committed upon the high seas, out of the body of any county of this realm, shall be and they are hereby declared to be offences...liable to the same punishments, respectively, as if they had been committed upon the shore.' The underlined wording in the first instance is spent. That in the second is obsolete (it dealt with the need for crimes to be located in a county for specific JP's to have jurisdiction).Thus, a modern re-statement would be 'Any crime or offence committed on the high seas is liable to the same punishment as if it had been committed on shore.'

${ }^{125}$ Ibid, Consolidating Public Order Offences in a new Crime Act (to be published).
} 
180

1806

1835
Writ of Subpoena Act

Witnesses Act

Treason Act

Vagrancy Act

Slave Trade Act

Universities Act

Juries Act

Criminal Law Act

Metropolitan Police Act

Roman Catholic Relief Act

Statutory Declarations Act

Highway Act

Piracy Act

Metropolitan Police Act

Metropolitan Police Courts Act

Railway Regulation Act

Treason Act

Slave Trade Act

Railways Clauses Consolidation Act

Companies Clauses Consolidation Act

Town Police Clauses Act
2
2 sections remain. Place in rules instead. Repeal Act. ${ }^{126}$ Superceded by Civil Evidence Act 1968. Repeal Act. ${ }^{127}$ Procedural. See above.

Section 4 (wandering) obsolete. Remainder should be in modern legislation. Repeal Act. ${ }^{128}$

Superceded by Modern Slavery Act 2015. Repeal Act. ${ }^{129}$

Obsolete re reference to Oxford university. Repeal wording. ${ }^{130}$

Challenge for cause. Place in modern legislation. Repeal Act.

Compensation for assisting. Prior to modern police force. Repeal Act.

Obsolete. Repeal Act. ${ }^{131}$

Section 18 is obsolete and has no caselaw. Repeal section. ${ }^{132}$

Section 13. Last case in 1843. No longer necessary. Repeal section. ${ }^{133}$

Insert sections (if required) in HighwaysAct 1980. Repeal Act. ${ }^{134}$

No cases. Obsolete (treats attempted murder as murder). Repeal Act. ${ }^{135}$

This applies to MPD only. Insert ss 38-9 (on processions) into the Highways Act 1980. Insert s 33 (searching vessels) into modern police legislation. Repeal Act. ${ }^{136}$

Concerns stolen goods. Obsolete. Applies to MPD only. Repeal Act. ${ }^{137}$

Insert s 16 into more modern railway legislation. Consolidate remainder with railway legislation. Repeal section. ${ }^{138}$

Assault. Needs to be modernised. Insert into modern legislation. Repeal Act.

Superceded by Modern Slavery Act 2010. RepealAct. ${ }^{139}$

Ss $23-4,54,57,75,103,116,119,144 \& 163$ are obsolete. Repeal these and consolidate Act (if needed) with railway legislation. Repeal sections. ${ }^{140}$

Section 162 (copy of Special Act). Repeal section. ${ }^{141}$

Applies to urban districts only. Insert ss $21 \& 23$ into

\footnotetext{
${ }^{126}$ Ibid, Our Criminal Law should only be 200 Years out of Date (2014) Review of European Studies, vol 6, no 2

${ }^{127}$ Ibid, Abolishing Obsolete Legislation on Bribery (2011) Coventry LJ, vol 16, no 2.

${ }^{128}$ Ibid, Modernising the law on Minor Public Order Offences (to be published).

${ }^{129}$ Ibid, Modernising the Slave Trade Acts 1824, 1843 and 1873 (2015) International Law Research, vol 4, no 1.

${ }^{130}$ GS McBain, Our Criminal Law should only be 200 Years out of Date (2014) Review of European Studies, vol 6, no 2.

131 The Metropolitan Police (Receiver) Acts 1861, 1867 and 1895 as well as the Metropolitan Police Acts 1886 , 1887 and 1889 , the Metropolitan Police Courts Act 1897 and the Police, Factories etc (Miscellaneous Provisions) Act 1916 are also obsolete.

${ }^{132}$ Information supplied to the Law Commission,

${ }^{133}$ Ibid, Abolishing Obsolete Legislation on Crimes \& Criminal Procedure (2010) Legal Studies, vol 30. No 3.

${ }^{134}$ See this article.

${ }^{135}$ Ibid, Abolishing Obsolete Legislation on Crimes \& Criminal Procedure (2010) Legal Studies, vol 30. No 3.

${ }^{136}$ Ibid. See also this article.

${ }^{137}$ Ibid,

${ }^{138}$ See this article.

${ }^{139}$ See $\mathrm{n} 129$.

${ }^{140}$ See this article.

${ }^{141}$ Ibid.
} 


\begin{tabular}{|c|c|c|c|}
\hline 1847 & Harbours, Docks and Piers Clauses Act & 5 & Ss $15,17,19,55 \& 62$ are obsolete. Repeal sections. ${ }^{143}$ \\
\hline 1847 & Markets and Fairs Clauses Act & 4 & Ss $16,19,40 \& 59$ are obsolete. Repeal sections. ${ }^{144}$ \\
\hline 1847 & Town Improvement Clauses Act & 1 & Section 215 (copy of special Act). Repeal section. ${ }^{145}$ \\
\hline 1847 & Commissioners Clauses Act & 1 & Section 111 (copy of special Act). Repeal section. ${ }^{146}$ \\
\hline 1848 & Treason Felony Act & 3 & See above. \\
\hline 1848 & Indictable Offences Act & 2 & Procedural. Modernise and place in rules. Repeal Act. \\
\hline 1849 & Admiralty Offences (Colonial) Act & 4 & $\begin{array}{l}\text { Section } 4 \text { is obsolete. Remainder needs to be modernised. } \\
\text { Repeal Act. }\end{array}$ \\
\hline 1850 & Piracy Act & 2 & $\begin{array}{l}\text { No cases. Superceded by Aviation and Maritime } \\
\text { Security Act } 1990 \text {. Repeal Act. }{ }^{\mathbf{1 4 7}}\end{array}$ \\
\hline 1851 & Criminal Justice Administration Act & 1 & Procedural. Place in rules. Repeal Act. \\
\hline 1853 & Criminal Procedure Act & 1 & Procedural. Place in rules. Repeal Act. \\
\hline 1857 & Penal Servitude Act & 2 & Penal servitude was abolished in 1948. Repeal Act. \\
\hline 1858 & Jews Relief Act & 1 & Section 4 is obsolete. Repeal section. ${ }^{148}$ \\
\hline 1859 & Remission of Penalties Act & 1 & Procedural. Needs to be modernised. Repeal Act. \\
\hline 1860 & Metropolitan Police Act & 5 & Obsolete. Repeal Act. \\
\hline 1860 & Admiralty Offences (Colonial) Act & 1 & Needs to be modernised. Repeal Act. \\
\hline 1861 & Accessories and Abettors Act & 2 & Needs to be modernised. Repeal Act. \\
\hline 1861 & Malicious Damage Act & 4 & Covered by OPA 1861 (see below). Repeal Act. ${ }^{149}$ \\
\hline 1861 & Forgery Act & 4 & Need to modernise. \\
\hline 1861 & Offences against the Person Act & 37 & $\begin{array}{l}\text { Law Commission has proposed repeal re assault crimes. } \\
\text { Modernise remainder. }\end{array}$ \\
\hline 1864 & Metropolitan Police Act & 1 & Obsolete. Applies to MPD only. Repeal Act. ${ }^{150}$ \\
\hline 1867 & Metropolitan Streets Act (street offences) & 8 & Obsolete. Applies to MPD only. Repeal Act. ${ }^{151}$ \\
\hline 1867 & Metropolitan Streets Act Amendment Act & 2 & Obsolete. Applies to MPD only. Repeal Act. ${ }^{152}$ \\
\hline 1867 & Criminal Law Amendment Act & 2 & Procedural. Place in rules. Repeal Act. \\
\hline 1868 & Regulation of Railways Act & 1 & $\begin{array}{l}\text { Section } 23 \text { obsolete. Insert remainder into modern railways } \\
\text { legislation. Repeal section. }{ }^{153}\end{array}$ \\
\hline 1869 & Debtors Act (s 13) & 1 & Needs to be modernised and placed in modern legislation. \\
\hline 1870 & Tramways Act & 5 & $\begin{array}{l}\text { Ss } 49-51,53 \& 55 \text { obsolete. Repeal. Insertremainder (if } \\
\text { required) into modern railway legislation. Repeal Act. }{ }^{154}\end{array}$ \\
\hline
\end{tabular}

\footnotetext{
${ }^{142}$ Ibid, Abolishing Obsolete Legislation on Crimes \& Criminal Procedure (2010) Legal Studies, vol 30. No 3. See also this article.

${ }^{143}$ Ibid.

144 Ibid.

145 Ibid.

${ }^{146}$ Ibid.

${ }^{147}$ See $\mathrm{n} 135$.

${ }^{148}$ See $\mathrm{n} 132$

${ }^{149}$ See this article.

${ }^{150}$ Ibid.

${ }^{151}$ Ibid.

152 Ibid.

153 Ibid.

154 Ibid.
}

Highways Act 1980. Modernise ss 37-68 on hackney carriages and insert into modern legislation. Repeal Act. ${ }^{142}$

Ss $15,17,19,55 \& 62$ are obsolete. Repeal sections. ${ }^{143}$

16, 19, 40 \& 59 are obsolete. Repeal sections. equired) into modern railway legislation. Repeal Act. ${ }^{154}$ 
1872

Explosives Act
Licensing Act

Parks Regulation Act

Slave Trade Act

Public Stores Act

Territorial Waters Jurisdiction Act

Convention (Ireland) Repeal Act

Explosive Substances Act

Sheriffs Act 1887
Only one case. 1976 Diplock Report proposed repeal. Repeal Act. $^{155}$

Modernise and insert into modern legislation. Repeal Act. ${ }^{\mathbf{1 5 6}}$

Section 7 (assaulting park officer). Not required. Repeal section. $^{157}$

Superceded by Modern Slavery Act 2010. Repeal Act. ${ }^{158}$

24 Needs to be modernised. Law Commission considering.

s 8 obsolete, brass shells no longer used. Modernise s 5 . Repeal section. ${ }^{159}$

Modernise and place in modern legislation. Repeal Act.

A contempt of Parliament. No caselaw. Obsolete. Repeal Act

Needs to be modernised. Law Commission considering.

S 27 superceded by Bribery Act 2010. Repeal section. ${ }^{160}$

After 1890, the following legislation pre-1970 should be repealed or modernised:

1898

1898

1902

1908

1911

1911

1920

1919

1934

1951

Total : 83 Acts
Town Police Clauses Act

Inebriates Act

Libraries Offences Act

Licensing Act

Public Meeting Act

Perjury Act

Official Secrets Act

Official Secrets Act

Aliens Restriction (Amendment) Act 19195

Incitement to Disaffection Act

Common Informers Act
Applies to horse-drawn buses only. Repeal, with s 5 placed in modern legislation on hackney carriages, in required. Repeal Act. ${ }^{16}$

Modernise and place in modern legislation. Repeal Act. ${ }^{162}$

Obsolete. Repeal Act.

Modernise and place in modern legislation. Repeal Act. ${ }^{163}$

Modernise and place in modern legislation. Repeal Act. ${ }^{164}$

Modernise and place in modern legislation.

Law Commission is considering this

Law Commission is considering this.

Section 3 obsolete, sedition abolished. Repeal section. ${ }^{165}$

Amend to tally with Police Act 1996, s 91. Repeal Act. ${ }^{166}$

Obsolete. Repeal Act

\footnotetext{
${ }^{155}$ GS McBain, Modernising Various Crimes against the State (2014) Journal of Politics and Law, vol 7, no 2.

${ }^{156}$ GS McBain, Consolidating Public Order Offences into a new Crime Act (to be published).

${ }^{157}$ See this article.

${ }^{158}$ See n 129.

${ }^{159}$ GS McBain, Abolishing Obsolete Legislation on Crimes \& Criminal Procedure (2010) Legal Studies, vol 30, no 3.

${ }^{160}$ See $n 127$

${ }^{161}$ See this article.

${ }^{162}$ See $n 156$.

${ }^{163}$ See $n 156$.

164 Ibid.

${ }^{165}$ GS McBain, Modernising Various Crimes against the State (2014) Journal of Politics and Law, vol 7, no 2.

166 Ibid.
} 


\section{Appendix C - Common Law Crimes}

The following appear to be common law crimes still extant:

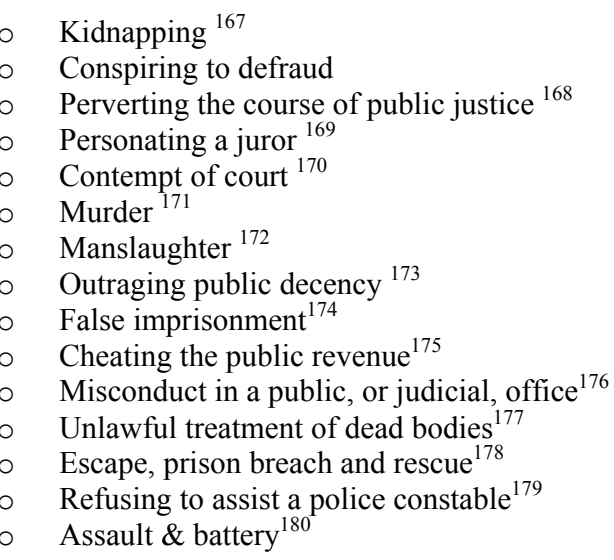

All the above should be statutory. The following common law crimes should be abolished, being obsolete:

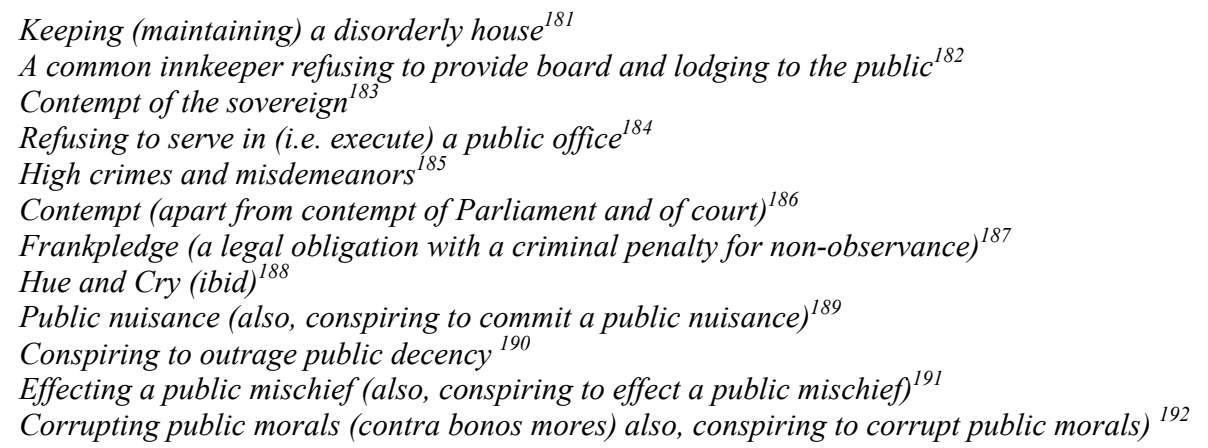

\footnotetext{
${ }^{167}$ See Law Commission, (2011) Kidnapping (no 200).

${ }^{168}$ See Law Commission, (2013) Juror Misconduct and Internet Publications. Also, (2013) Court Reporting.

${ }^{169}$ Ibid.

${ }^{170}$ Ibid.

${ }^{171}$ See Law Commission, Murder, Manslaughter and Infanticide (2006) HC 30, no 304. Also, (2004) Partial Defences to Murder (Cm 6301, no 290). See also GS McBain, Modernising the Law of Murder and Manslaughter (2015) Journal of Politics and Law, vol 8, no 4.

${ }^{172}$ Ibid.

${ }^{173}$ The Law Commission has recommended this become a statutory crime. One would agree. See Law Commission, (2010) Public Nuisance and Outraging Public Decency (no 193).

${ }^{174}$ See GS McBain, False Imprisonment and Refusing to Assist a Police Officer (2015) Journal of Politics and Law, vol 8, no 3.

${ }^{175} \mathrm{Ibid}$, Modernising the Common Law offence of Cheating the Public Revenue (2015) Journal of Politics and Law, vol 8, no 1.

${ }^{176} \mathrm{Ibid}$, Modernising the Common Law offence of Misconduct in a Public or Judicial Office (2014) Journal of Politics and Law, vol 7, no 4.

${ }^{177}$ Ibid, Modernising the Law on the Unlawful Treatment of Dead Bodies (2014) Journal of Politics and Law, vol 7, no 3.

${ }^{178}$ This is analysed in GS McBain, Modernising the Law on Escape, Prison Breach and Rescue (2014) Rev European Studies, vol 6, no 4.

${ }^{179}$ See n 174.

${ }^{180}$ See GS McBain, Modernising the Common Law offences of Assault and Battery (2015) International Law Research, vol 4, no 1.

${ }^{181} \mathrm{Ibid}$, Abolishing the Common Law offence of Keeping a Disorderly House (2015) Journal of Politics and Law, vol 8, no 2.

${ }^{182}$ Ibid, Abolishing some Obsolete Common Law Crimes (2009) 20 KLJ 89-114.

${ }^{183}$ Ibid.

${ }^{184}$ Ibid.

${ }^{185}$ Ibid, Abolishing High Crimes and Misdemeanours etc.(2011) 85 ALJ 810-79.

${ }^{186}$ See $\mathrm{n} 185$.

${ }^{187} \mathrm{~J}$ Ritson, The Jurisdiction of the Court Leet (2nd ed, 1809), pp vi-ii, frankpledge had sunk into 'total disuse, there not having been any freepledges in the kingdom for two or three centuries.' See also Mc Bain, n 143 and GS McBain, Modernising the Law: Breaches of the Peace and Justices of the Peace (2015) Journal of Politics and Law, vol 8, no 3.

${ }^{188}$ See Mc Bain, n 174 and GS McBain, Modernising the Law: Breaches of the Peace and Justices of the Peace (2015) Journal of Politics and Law, vol 8, no 3.

${ }^{189}$ See Law Commission, (2010) Public Nuisance and Outraging Public Decency (no 193). Also, GS McBain, Abolishing the Crime of Public Nuisance and Modernising that of Public Indecency (2017), vol 6, no 1.

${ }^{190}$ The Law Commission has recommended this become a statutory crime. One would agree. See Law Commission, (2010) Public Nuisance and Outraging Public Decency (no 193). See also McBain, n 189.

${ }^{191}$ The House of Lords in DPP $v$ Withers [1975] AC 842 held there was no offence of conspiring to effect a public mischief. However, a number of prior cases were decided on the opposite basis (indeed, public mischief seems to have been little more than a re-naming of the crime of 'cheat', itself, 16th Romany cant for the medieval crime of 'deceite'). Thus, for the avoidance of doubt, it would seem wise to formally abolish public mischief (which will also abolish any conspiring in respect of the same). See also McBain, n 189.
} 
'Breach of the Peace.' This is not a crime as such. However, it should be replaced by a reference to a 'breach of the criminal $l a w^{\prime}$ which is what it means today (albeit, the legislative context indicates which crimes are involved). ${ }^{193}$

\section{Copyright}

Copyright for this article is retained by the author(s), with first publication rights granted to the journal.

This is an open-access article distributed under the terms and conditions of the CreativeCommons Attribution license (http://creativecommons.org/licenses/by/4.0/).

\footnotetext{
${ }^{192}$ A number of cases adopted this description and it is uncertain the extent to which the crime of 'Outraging Public Decency' has superceded it. Thus, for the avoidance of doubt, it would seem wise to formally abolish it. See also McBain, $\mathrm{n} 189$.
}

${ }^{193}$ See GS McBain, Modernising the Law: Breaches of the Peace and Justices of the Peace (2015) Journal of Politics and Law, vol 8, no 3. 